\title{
Effect of Integrated Sources of Nutrients on Growth, Flowering, Yield and Soil Quality of Floricultural Crops: A Review
}

\author{
Mukesh Kumar $^{1 *}$ and Veena Chaudhary ${ }^{2}$ \\ ${ }^{1}$ Department of Horticulture, Sardar Vallabhbhai Patel University of Agriculture and \\ Technology, Meerut, UP-250110, India \\ ${ }^{2}$ Department of Chemistry, CSSS (PG) College, Machhra, Meerut, UP-250106, India \\ *Corresponding author
}

\section{Keywords \\ Organic manure, Inorganic fertilizers, Bio-fertilizers, INM, Soil quality, Flowers \\ Article Info \\ Accepted: \\ 20 February 2018 \\ Available Online: \\ 10 March 2018}

\section{A B S T R A C T}

Now a days agriculture is getting more and more dependent upon the supply of synthetic inputs such as chemical fertilizers, pesticides etc. which are inevitable to meet food demand for growing population in the world. However, excessive, imprudent and imbalanced use of inputs may throw devastating impacts on the water, air and soil environments. Probably the soil environment is the most vulnerable to the direct effects of these practices in modern agriculture. They could destroy the fertility of the soil in a long run which compels the scientific community to look for the alternatives like organic farming and integrated use of organic and inorganic fertilizers. In the present review, we discuss the role of INM in resolving these concerns, which has been proposed as a promising strategy for addressing these challenges. INM has multifaceted potential for the improvement of plant performance and resource efficiency while also enabling the protection of the environment and resource quality. Lower inputs of chemical fertilizer and therefore lower human and environmental costs (such as intensity of land use, $\mathrm{N}$ use, reactive $\mathrm{N}$ losses and GHG emissions) were achieved under advanced INM practices without any negative effect on crop yields. An available comparative literature research revealed that INM increases crop growth and yield of floricultural crops as compared with conventional methods. INM practices increases nutrients use efficiency and improving soil health and sustainability. Strong and convincing evidence indicates that INM practice could be an innovative and environment friendly practice for sustainable growth and yield of floricultural crops.

\section{Introduction}

Floriculture is the segment of horticulture concerned with commercial production, marketing, and sale of bedding plants, cut flowers, potted flowering plants, foliage plants, flower arrangements, and noncommercial home gardening. Floriculture crops include bedding plants, flowering plants, foliage plants or house plants, cut cultivated greens, and cut flowers. As distinguished from nursery crops, floriculture crops are generally herbaceous. Bedding and garden plants consist of young flowering plants (annuals and perennials) and vegetable plants. They are grown in cell packs (in flats or trays), in pots, 
or in hanging baskets, usually inside a controlled environment, and sold largely for gardens and landscaping. Geraniums, impatiens, and petunias are the best-selling bedding plants. Floriculture is an ancient farm activity with immense potential for generating remunerative self-employment among small and marginal farmers. Flowers are being cultivated in India from time immemorial. Since ancient times ornamental plants have been an integral part of life with gardens, flowers, and ornamental horticulture being noted in most of our historical references.

According to The International Association of Horticultural Producers (AIPH, 2010), 702,383 ha area was under flower production in different countries of the world, of which the total area in Europe was 48,705 ha, 1,067 ha in North America, 523,829 ha in Asia, 4,026 ha in middle East, 7,604 ha in Africa, 21,067 ha in North America and and South America, it was the 97,152 ha. The total area under floriculture in India is 248.51 thousand hactare with production of 1685 thousand tonnes loose flowers and 472 thousand tonnes of cut flowers during 2014-15 (www.apeda.gov.in). Total export of floriculture products during the year 2015-16 was 22,518 MT with value of Rs. 479 crores (www.apeda.gov.in). To increasing the production and get more income by flower production in the country, There is as such an urgent need of scientific approach and wise use to promote the relevant management practices, improvement of flower germplasm, balanced nutrient management, modern production technology, quality planting material, precision farming etc., for conservation and commercialization of the floriculture industry and diversification from the traditional field crops due to higher returns per unit area. The overall strategy for increasing crop yields and sustaining them at high level must include integrated approach to the management of nutrients (Wani et al.,
2017). Integrated nutrient management (INM) programme is a critical component of the type of integrated farming systems (Edwards et al., 1990). The program involves maximize biological inputs to crop production and minimize the use of inorganic amendments so as to create a much more sustainable pattern of crop production, not only ecologically but also environmentally (National Research Council, 1991). Integrated Nutrient Management in floricultural crops is very important to address the issues like poor quality of cut flowers and planting material, inappropriate planting methods and fertilization practices which result in low yield and production.

One of the factors affecting the productivity of most of the floricultural crops is improper use of nutrients. To improve the productivity, adequate amount of fertilizers in balanced proportion should be used which has been given less attention by the flower growers or floriculturists.

\section{Why integrated nutrient management is needed in floricultural crops?}

INM is very essential to address the following issues:

The decline in productivity can be attributed to the appearance of deficiency in secondary and micronutrients.

The physical condition of the soil is deteriorated as a result of long-term use of chemical fertilizers

The recent energy crisis, high fertilizer cost and low purchasing power of the farming community have made it necessary to rethink alternatives.

Unlike chemical fertilizer, organic manure and bio-fertilizer are available locally at cheaper rates 


\section{Principles of Integrated Nutrient from hidden deficiencies and nutrient Management (INM) imbalance.}

The main principle of INM is to maximize biological potential for improving crop productivity and resources use efficiency through root zone/rhizosphere management. Plant roots take up nutrients from soils via the rhizosphere, a narrow zone of the soil that is directly influenced by root growth, root secretions, and associated soil microorganisms (Zhang et al., 2012). The rhizosphere is the important interface where interactions among plants, soils, and microorganisms occur and is a "bottleneck" controlling nutrient transformations, availability, and flow from soils to plants. Therefore, the chemical and biological processes occurring in the rhizosphere determine the mobilization and acquisition of soil nutrients together with microbial dynamics, and also control NUE by crops, and thus profoundly influence cropping system productivity and sustainability (Zhang et al., 2004, 2010, 2011, 2012).

The principle of INM is to control the $\mathrm{N}$ losses and their harmful environmental effects, while achieving high crop productivity (Gruhn et al., 2000). The fate of $\mathrm{N}$ in field is an integrated consequence of crop $\mathrm{N}$ uptake, immobilization and residues in the soil, and $\mathrm{N}$ losses to the environment, such as ammonia volatilization, NOX emissions, denitrification, $\mathrm{N}$ leaching and runoff (Witt et al., 2004).

\section{Advantages of INM}

Enhances the availability of applied as well as native soil nutrients

Synchronizes the nutrient demand of the crop with nutrient supply from native and applied sources.

Provides balanced nutrition to crops and minimizes the antagonistic effects resulting

Improves and sustains the physical, chemical and biological functioning of soil.

Minimizes the deterioration of soil, water and ecosystem by promoting carbon sequestration, reducing nutrient losses to ground and surface water bodies and to atmosphere

\section{Disadvantages of INM}

Organic sources used in INM are comparatively low in nutrient content, so larger volume is needed to provide enough nutrients for crop growth.

The nutrient composition of compost and FYM is highly variable; the cost is high as compared to chemical fertilizers.

\section{Components of INM}

\section{Organic manures}

Organic manures are valuable by-products of farming and allied industries, derived from plant and animal sources. These manures have the advantage of supplying secondary and micro nutrient along with NPK, which is important for sustained production

\section{Farm Yard Manure (FYM)}

FYM is a decomposed mixture of dung and urine of farm animals along with the litter (bedding material) and left-over material from roughages or fodder fed to the cattle. On an average, it contains $0.5 \% \mathrm{~N}, 0.2 \% \mathrm{P}_{2} \mathrm{O}_{5}$ and $0.5 \% \mathrm{~K}_{2} \mathrm{O}$

\section{Enriched organic manure}

The enriched farmyard manure is prepared by using $10 \mathrm{~kg}$ of rock phosphate and $10 \mathrm{~kg}$ of 
each biofer- tilizers viz., Azospirillum, Azotobacter and Phosphobacteria is thoroughly mixed with $1000 \mathrm{~kg}$ of decomposed and powdered farmyard manure on dry weight basis and made into a heap like structure. The heap is kept for 60 days for composting under the shade with $60 \%$ moisture. For enriched poultry manure compost, $20 \mathrm{~kg}$ of rock phosphate and $10 \mathrm{~kg}$ of each biofertilizers viz., Azospirillum, Azotobacter and Phosphobacteria are thoroughly mixed with $1000 \mathrm{~kg}$ of poultry manure on dry weight basis and made into a heap like structure. The heap is kept for 60 days for composting under the shade with $60 \%$ moisture (Sims et al., 1992)

\section{Vermicompost}

Compost made from the biological activity of earthworms. It contains $1.9 \% \mathrm{~N}, 2.0 \% \mathrm{P}$ and $0.8 \% \mathrm{~K}, 100 \mathrm{mg} / \mathrm{Kg} \mathrm{Cu}$ and $500 \mathrm{mg} / \mathrm{kg} \mathrm{Mn}$. Earthworms effectively harness the beneficial soil micro flora, destroy soil pathogens and convert organic wastes into valuable products known as cast which contains biofertilizers, vitamins, enzymes, antibiotics, growth hormones and proteinaceous worm biomass. Hence, earthworms are called as 'artificial fertilizer factories'. The exotic species used for making vermicompost are Eisenia foetida, Eudrillus euginiae and Perionyx excavatus, while indeginous species include Lampito mauriti, and Perionyx sansibaricus

\section{Poultry manure}

It is rich organic manure, since liquid and solid excreta are excreted together resulting in no urine loss.

\section{Green Manuring}

Green manure crops are grown usually for restoring or enhancing soil organic matter content, properties of soil and nitrogen content in the soil and their use in cropping system is called green manuring. Legumes are generally used as green manure crops due to their ability to fix atmospheric nitrogen in the root nodules through symbiotic association with a bacterium

According to the Chandra (2005), there are different green leaf manure crops that can be cultivated and they are:

\section{Cowpea}

Cowpea is one of the important leguminous green leaf manure crops. As this plant is easily decomposable and very well suited for green manure purpose. June-July months are best suited for sowing of this manure. Even though it is being cultivated in summer months (March to April). Use of effective Rhizobium bacteria increase the fixation of nitrogen up to $40 \mathrm{~kg} / \mathrm{ha}$.

\section{Dhaincha (Sesbania aculeate)}

Dhaincha is suitable for loamy and clayey soils. It is fairly resistant to drought as well as stagnation of water. It grows well even in alkaline soils and corrects alkalinity if grown repeatedly for 4-5 years. The roots have plenty of nodules. It yields about 10-15 tonnes of green manure per ha and requires a seed rate of $30-40 \mathrm{~kg} / \mathrm{ha}$. Use of effective Rhizobium strain with seeds fixes the Nitrogen $1 \mathrm{~kg} / \mathrm{day}$.

\section{Sesbania Speciosa}

It is a valuable green manure for wetlands and can be grown in a wide range of soils. Seed production is prolific however, its pods are frequently attacked by insects. This green manure can be raised on the field borders. Sesbania seedling (21days) can be planted in a single line at $5-10 \mathrm{~cm}$ apart in the borders of the fields. In about 90 days it produces about 2-4 tonnes of green manure per ha. It does not 
affect the rice yield by shading or root effect. If second rice crop is planted immediately after the first crop, the manure can be incorporated into the field. About 300-400g of seeds are sufficient to raise nursery foe one ha area. To control insects Verticillium lacanii (Liquid) fungi is useful.

\section{Sunnhemp (Crotalaria juncea)}

It is a quick growing green manure crop and gets ready for incorporation in about 45 days after sowing. It does not withstand heavy irrigation leading to flooding. The crop is at times subject to complete damage by leaf eating caterpillars.

The crop can produce about 8-12 tonnes of green biomass per ha. The seed requirement is $30 \mathrm{~kg} / \mathrm{ha}$.

\section{Sesbania rostrata}

One of the important features of this green manure is to produces nodules in the stem in addition to root nodules. The stem nodulation is an adaptation for waterlogged situation since flooding limits growth of green manures and may reduce root nodulation. Under normal condition, both root and stem nodules are effective in $\mathrm{N}$ fixation. It has higher $\mathrm{N}$ content of $3.56 \%$ on dry weight basis. Biomass production is higher during summer (April - June) than in winter (Dec. - Jan.) season. This green manure can also be produced by raising seedlings (30 days old) and planted in the paddy field along the bunds or as intercrop with rice. Use of Rhizobium bacteria increase the nitrogen fixation (60-100 $\mathrm{kg} / \mathrm{ha} /$ year).

\section{Wild Indigo (Tephrosia purpurea)}

This is a slow growing green manure crop and cattle do not prefer to graze it. The green manure is suitable for light textured soils, particularly in single crop wetlands. It establishes itself as a self-sown crop and the seeds remain viable till the harvest of rice. On an average about 3-4 tonnes of green manure is obtained in one ha. The seed rate is 30 $\mathrm{kg} / \mathrm{ha}$. The seeds have a waxy impermeable seed coat and hence scarification is required to induce germination. Soaking seeds in boiling water for 2-3 minutes is also equally effective in promoting germination.

\section{Indigo (Indigofera tinctoria)}

It resembles wild indigo and is a long duration crop with more leafy growth. It comes up well in clayey soils with one or two irrigations.

\section{Pillipesara (Pheseolus trilobus)}

This is a dual purpose crop yielding good fodder for the cattle and green manure. Pillipesara comes up well in hot season with sufficient soil moisture. Loamy or clayey soils are best suited.

After taking one or two cuttings for fodder or light grazing by animals, the crop can be incorporated into the soil. About 5-8 tonnes of manure can be obtained from one ha.

\section{Glyricidia (Glyricidia maculeata)}

This is a shrubby plant that comes up well in moist situations. Under favourable conditions, it grows well like a tree. It can be easily grown in waste lands, farm road sides, field bunds, etc.

The crop can be established by stem cuttings or seedlings. It is planted on the field borders. It can be pruned for its tender loppings and compound leaves for green leaf manuring at the time of puddling rice. On an average, a well-established plant yields $12-15 \mathrm{~kg}$ green matter. About 400 plants on the peripheral bunds yields 5-6 tonnes green manure/ha. 


\section{Karanj (Pongamia glabra)}

It is a leguminous tree grown in wastelands. On an average, a tree can yield $100-120 \mathrm{~kg}$ of green matter. The leaves contain about $3.7 \%$ $\mathrm{N}$ (on dry weight basis).

\section{Calatropis (Calotropis gigantca)}

On roadsides and fallow lands, the plant grows wild under different soil and climatic conditions. The leaves are more succulent and a plant can produce about $4-5 \mathrm{~kg}$ of green matter. Besides, it also helps in controlling soil born pests like termite

\section{Oil cakes}

Many kinds of oilcakes can be used in crops as a source of nutrients. Nutrients present in oil cakes, after mineralization, are made available to crops 7 to 10 days after application. Before application to the flowering crop, oilcakes should be wellpowdered to facilitate their application and decomposition by soil microorganisms. Depending on crop, oilcakes are applied broadcast, drilled or placed near the root zone. The oil cakes are of two types.

Edible oil cakes which can be safely fed to livestock; e.g.: Groundnut cake, Coconut cake, Niger cake, Rape seed cake, Sesame cake etc.

Non edible oil cakes which are not fit for feeding livestock; e.g.: Castor cake, Neem cake, Mahua cake, Safflower cake etc

\section{Biogas slurry}

Biogas (Gobar gas) plant produces methane and biogas slurry, which could be used as a valuable manure in bulbous flower crops. Biogas slurry is quite rich in nitrogen than the original ingredients due to addition of living and dead micro-organisms. Biogas slurry also contains phosphates, potash, sulphur and a number of micro-nutrients like zinc and iron. Biogas slurry is extremely cheap and is made by locally available material. It can be directly used in rice after mixing with irrigation water.

\section{Urine}

Animal urine is a very good source of nitrogen, because $60 \%$ of the nitrogen excreted is found in urine and only $40 \%$ in manure. As few as two cattle can save the cash equivalent of purchasing about $100 \mathrm{~kg}$ of urea per year. Urine can be applied directly as liquid fertiliser (WOCAT, 2008).

\section{Liquid manures}

These can be made using fresh plant material (plant tea), compost (compost tea) or fresh animal manure (manure tea). Manure tea and plant tea are both rapid sources of nitrogen, while compost tea is a more nutritionally balanced liquid fertiliser.

\section{Plant tea}

Fresh and green material is soaked in water for several days or weeks to undergo fermentation. Nutrient- or nitrogen-rich material should be used.

\section{Ashes}

The ashes of burnt organic material are often also used as organic fertiliser. Ash provides a rapid supply of phosphorous; however burning organic material also includes a loss of other nutrients and thus has severe long-term consequences.

\section{Biofertilizers scenario}

The biofertilizers market is projected to grow at a CAGR of $14.08 \%$ from 2016, to reach USD 2,305.5 million by 2022 (Biofertilizers 
Market Analysis, Grand View Research, San Francisco, USA). The market is driven by factors such as: i) increase in demand for fertilizers due to the rise in global food production and ii) development of new biofertilizer manufacturing technologies. The high growth potential in emerging markets and untapped regions provide new growth opportunities for the players in the biofertilizers market.

On the other hand, some factors restraining the biofertilizers market are lack of awareness and low adoption of biofertilizers coupled with poor infrastructure. Although biofertilizers were first commercialized in North America and Europe, there is increasing preference towards their use in parts of Asia Pacific and South America. North America was the largest market for biofertilizers, followed by Europe. Together these markets accounted for over $50 \%$ of the global revenue.

Asia Pacific is the third largest market for biofertilizers, with increased demand from regional markets such as India, China and Taiwan. Asia Pacific is expected to witness double-digit growth over the period 2013 to 2020 due to the increased consumer preference towards organic food and growing agricultural activities. However, contrary to other regions, the key application of biofertilizers in Asia Pacific is soil treatment but not seed treatment.

In India, during the 2008-09, the production of bio-fertilizers was 25065.035 ton which increased to 20040.36 and 37997.61ton in 2009-10 and 2010-11 and reached 80696.46 ton in 2014-15 (NCOF, 2014 and 2015). It is estimated that the present requirement of biofertilizers is around 5,50,000 metric tonnes and there is an ample potential to increase it to $50,000-60,000$ tons by 2020 (Pindi and Satyanarayana, 2012); however, the total production of biofertilizers in our country is much less than requirement which points out the inevitability of increase in biofertilizer production. Biofertilizers can be grouped in to five catagories (Barman et al., 2017)

Nitrogen $\left(\mathbf{N}_{2}\right)$ fixing Biofertilizers: It can be sub group in three category

Free-living- Example, Azotobacter, Clostridium, Anabaena, Nostoc

Symbiotic - Example, Rhizobium, Frankia, Anabaena azollae

Associative Symbiotic- Example, Azospirillum

\section{P-solubilizing biofertilizers}

Bacteria- Example, Bacillus megaterium var. phosphaticum, Bacillus circulans, Pseudomonas striata

Fungi- Example, Penicillium sp., Aspergillus awamori

\section{P-mobilizing biofertilizers}

Arbuscular mycorrhiza- Example, Glomus sp., Gigaspora sp., Acaulospora sp., Scutellospora sp., Sclerocystis $s p$.

Ectomycorrhiza -Example, Laccaria sp., Pisolithus sp., Boletus sp., Amanita sp.

Orchid mycorrhiza - Example, Rhizoctonia solani

\section{Biofertilizers for micro nutrients}

Silicate and zinc solubilizers-Example, Bacillus sp.

\section{Plant growth promoting Rhizobacteria}

Pseudomonas- Example, Pseudomonas fluorescens 


\section{Application of biofertilizers}

Seed treatment was the largest application of biofertilizers and accounted for over $70 \%$ of the market in 2012. Treating seeds with biofertilizers helps them sustain bacteria and virus attacks and also helps increasing the yield. In addition, biofertilizers help in harnessing atmospheric nitrogen and making it available to the plant. Seed treated with biofertilizers are capable of increasing phosphorous content of soil by solubilizing it and improving availability. Soil treatment is the other primary application of biofertilizers and it involves the spraying of biofertilizers over the agricultural land. It increases the fertility of the soil and improves the yields of the planted crop.

\section{Biofertilizers}

It is well known fact that some biofertilizers fixed the atmospheric $\mathrm{N}$ and can be increased by organisms such as Rhizobium, Azotobacter, blue green algae, Azolla/Anabaena (Gaur and Singh, 1995). The commonly used organic fertilizers/biofertilizers are as follows

\section{Azotobacters and Azospirillum}

These are free-living bacteria that fix atmospheric nitrogen in cereal crops without any symbiosis and they do not need a specific host plant. Azotobacters are abundant in well drained and neutral soil. They can fix 15-20 $\mathrm{kg} / \mathrm{ha} \mathrm{N}$ per year. Azotobacter sp. can also produce antifungal compounds to fight against many plant pathogens.

\section{Rhizobia}

Rhizobia are symbiotic bacteria that fix atmospheric $\mathrm{N}_{2}$ gas in plant root nodules and have a mutually helpful relationship with their host plants. The plant roots supply essential minerals and newly synthesized substances to the bacteria. Rhizobium inoculation is a wellknown agronomic practice to ensure adequate $\mathrm{N}$ supply for legumes in place of $\mathrm{N}$ fertilizer

\section{Plant growth promoting rhizobacteria (PGPR)}

PGPR represent a wide variety of soil bacteria which, when grown in association with a host plant, result in stimulation of host growth. PGPR modes include fixing $\mathrm{N}_{2}$, increasing the availability of nutrients in the rhizosphere, positively influencing root growth and morphology and promoting other beneficial plant-microbe symbioses. Some researchers have indicated that PGPR will often have multiple modes of action. Ratti et al., (2001) found that a combination of the arbuscular mycorrhizal fungi Glomus aggregatum, the PGPR Bacillus polymyxa and Azospirillum brasilense maximized biomass and $\mathrm{P}$ content of the aromatic grass palmarosa (Cymbopogon martinii) when grown with an insoluble inorganic phosphate.

\section{Phosphate-solubilizing bacteria (PSB)}

Under acidic or calcareous soil conditions, large amounts of phosphorus are fixed in the soil but are unavailable to the plants. Phosphobacterins, mainly bacteria and fungi, can make insoluble phosphorus available to the plant. The solubilization effect of phosphobacterins is generally due to the production of organic acids that lower the soil $\mathrm{pH}$ and bring about the dissolution of bound forms of phosphate. It is reported that PSB culture increased yield up to $200-500 \mathrm{~kg} / \mathrm{ha}$ and thus 30 to $50 \mathrm{~kg}$ of superphosphate can be saved.

\section{Vesicular arbuscular mycorrhiza (VAM)}

Mycorrhizae are mutually beneficial (symbiotic) relationships between fungi and plant roots. VAM fungi infect and spread 
inside the root. They possess special structures known as vesicles and arbuscules. The plant roots transmit substances (some supplied by exudation) to the fungi, and the fungi aid in transmitting nutrients and water to the plant roots. Some VAM fungi form a kind of sheath around the root, sometimes giving it a hairy, cottony appearance. Because they provide a protective cover, mycorrhizae increase seedling tolerance to drought, to high temperatures, to infection by disease fungi and even to extreme soil acidity.

\section{Inorganic fertilizer scenario}

According to the Food and Agriculture report world demand for total fertilizer nutrients is estimated to grow at $1.8 \%$ per annum from 2014 to 2018. The demand for nitrogenous, phosphatic, and potash is forecasted to grow annually by $1.4 \%, 2.2 \%$, and $2.6 \%$, respectively, during the period. Over the next five years, the global capacity of fertilizer products, intermediates and raw materials will increase further. The global demand for nitrogenous fertilizers is expected to grow around $5.6 \%$ to $119.4 \mathrm{MT}$ in four years through 2018, according to the Food and Agriculture Organization of the United Nations. Asian nations, led by China and India, are expected to account for $58 \%$ of this increase.

India is the 2nd largest consumer of fertilizers in the world, after China and USA. India also ranks second in the production of nitrogenous fertilizers and third in phosphatic fertilizers whereas the requirement of potash is met through imports since there are limited reserves of potash in the country. It accounts for $12.2 \%$ of the world's production of nitrogenous $(\mathrm{N})$ and phosphatic $(\mathrm{P})$ nutrients and $12.6 \%$ of the world's consumption of NPK. However, India's annual consumption of chemical fertilizers in nutrient terms (NPK), has increased from 0.7 lakh MT in
1951-52 to 277.39 lakh MT 2011-12 and it has been reached 413.24 lakh MT of fertilizers during the year 2016-17. Urea dominates the total fertilizer production in the country. While India is the world's second largest consumer of urea, the Government of India is working towards increasing the production of urea so as to end imports by 2022 and achieve self-sufficiency in urea production (Fig. 1 and 2 ). The Figure 3 clearly indicates that the maximum production of urea in the year 201516 was 244.8 LMT which was decreased to 241.9 LMT during the year 2016-2017. The data revealed in Figure 4 the maximum urea imported by the India was 87.49 LMT during 2014-15 and it was decreasing in 2015-16 and 2016-17 respectively. The data produced in the Figure 5 clearly demonstrates that the total DAP production was 36.5 LMT during 201213 and it was decreased in 2013-14. The data also showed that during the year 2015-16, the total production of DAP was 37.9 LMT and it was again increased upto 43.3 LMT during the year 2016-17. The data given in Figure 6 clearly demonstrates that during the year 2012-13, the total DAP imported from the other countries was 57.02 LMT which was decreased during the year 2013-14 and the total quantity was $32.61 \mathrm{LMT}$. The maximum DAP (60.80 LMT) was imported during the year 2016-17 and it was again decreased during the year 2016-17. Among the total fertilizers, MOP is totally imported from the other countries. The data pertaining in Figure 7 demonstrates that the maximum MOP (41.97 LMT) was imported during the year 2014-15 and the minimum MOP imported during the year 2012-13. In the year 2015-16 lesser MOP was imported as compared to the 2014-15 but the MOP quantity again increased during the year 2016-17 and its reached upto 37.36 LMT. Out of the total fertilizer production, India produces only $10 \%-12 \%$ of DAP but due to recent fall of raw material prices in the international markets, phosphates have become cheaper and its economical to 
produce the fertilizer rather than importing the end product. Hence, the government is encouraging sprucing up the production of DAP, which is the second most widely used fertilizer after urea. Production of Complex Fertilizers includes the various grades of NPK Fertilizers (Nitrogenous- PhosphorusPotassic). The Government is encouraging SSP production as SSP is also considered as a substitute to diammonium phosphate (DAP), which is largely import based and costlier visa-vis to SSP.

\section{Types of fertilizers}

A fertilizer is a chemical product either mined or manufactured material containing one or more essential plant nutrients that are immediately or potentially available in sufficiently good amounts.

Chemicals fertilizers are classified on the basis of quantum required by the soil as Primary, Secondary and Micronutrients. Primary nutrients are further categorized on the type of nutrients they are supplied to the soil which are as nitrogenous, phosphatic and potassic fertilizers.

Secondary nutrients include calcium, magnesium and Sulphur while micronutrients, include iron, zinc, copper, boron and chlorine. India is dependent on imports for raw materials for production of Nitrogenous \& Phosphatic fertilizers. Product wise Chemical Fertilizers are classified into Urea, Diammonium Phosphate (DAP), Single Super Phosphate (SSP), Muriate of Potash (MOP) and other Complex fertilizers like Calcium Ammonium Nitrate (CAN) and various grades of NPK Fertilizers (Fertilizers having different grades of Nitrogen $(\mathrm{N})$, Phosphorus $(\mathrm{P})$, and Potassium (K)). In India the most widely used fertilizers in the Nitrogenous category are Urea, DAP and MOP for Phosphorus and Potassium respectively.

\section{Different methods of Integrated Nutrient Management (INM) in crops}

\section{Combined use of chemical and organic fertilizers}

The integrated nutrient management system is an alternative and is characterized by reduced input of chemical fertilizers and combined use of chemical fertilizers with organic materials such as animal manures, crop residues, green manure and composts.

Management systems that rely on organic inputs as plant nutrient sources have different dynamics of nutrient availability from those involving the use of chemical fertilizers. For sustainable crop production, integrated use of chemical and organic fertilizer has proved to be highly beneficial.

Combined use of biofertilizers with chemical or organic fertilizers

In this system, the nutrients provided to the crops by combined use of i.e. biofertilizers, chemical fertilizers and organic materials such as animal manures, crop residues, green manure and composts.

\section{Impact of Integrated Nutrient Management (INM) on soil quality of harvested flowers field}

An experiment was conducted by Sharma et al., (2017) at Indian Agricultural Research Institute, New Delhi to study the effect of efficient micro-organism compost on plant growth and soil health in calendula and marigold.

The results showed that the application of EM compost improves the humus content, organic carbon and available nitrogen status of soil which in turn increased the soil fertility over the control receiving chemical fertilizer only. 
soil enzyme activities, e.g., dehydrogenase, $\beta$ glucosidase and acid phosphatase activity, are enhanced with the increase in the rate of application of EM composts along with half dose chemical fertilizer. Highest dehydrogenase activity $\left(10.46 \mathrm{~g} \mathrm{TPF} \cdot \mathrm{g}^{-1} \cdot \mathrm{d}^{-1}\right)$, acid phosphatase activity $\left(82.63 \mathrm{~g} \mathrm{NP} \cdot \mathrm{g}^{-1} \cdot \mathrm{h}^{-1}\right)$ and $\beta$-glucosidase activity $\left(0.30 \mathrm{IU} \cdot \mathrm{g}^{-1}\right)$ were observed in treatment receiving $20000 \mathrm{~kg}$. $\mathrm{hm}^{-2}$ EM compost with half of the recommended dose of NPK and lowest dehydrogenase activity was observed in the plots received full dose of NPK by chemical fertilizers.

Khanam et al., (2017) found the improvement in the available $\mathrm{N}, \mathrm{P}$ and $\mathrm{K}$ nutrients by the integrating use of $50 \%$ recommended dose of fertilizers (RDF) with 2.5 ton/ha of vermicompost in harvested soil of gladiolus.

Sathyanarayana et al., (2017) studied the effect of integrated nutrient management on Gladiolus (Gladiolus grandiflorus L.) cv. American Beauty who recorded the minimum soil electrical conductivity $(0.67 \mathrm{dSm}-1)$ and highest available nitrogen (178.73 kg/ha), available phosphorus (19.48 $\mathrm{kg} / \mathrm{ha})$, available potash $(314.13 \mathrm{~kg} / \mathrm{ha})$, soil organic carbon $(0.80 \%)$ and microbial population $(90.67 \times 10-$ 7 CFU/g soil) with 100\% RDF + FYM @ 7.5 t/ha + Azotobacter + PSB + KMB $+1 \%$ foliar spray of Nauroji Novel Organic Liquid Fertilizer while Dikr and Belete (2017) concluded that organic manure has a role in improving the soil chemical as well as physical properties of soil.

They further reported that the role of biofertilizers containing symbiotic or nonsymbiotic nitrogen-fixing bacteria in augmenting vegetative growth characters, yield and yield components, essential oil productivity and/or chemical composition (including chlorophyll a, b and carotenoids and/or N, P and K leaf percent and content
Application of Integrated Nutrient Management (INM) in some floricultural crops

China aster (Callistephus chinensis (L) Nees)

Kulkarni, (1994) recorded increased growth and dry weight of China aster with the application of vermicompost at 2.5 to 5.0 tonnes per ha alone or in combination with organic fertilizer. Srinivas (1994) stated that the application of NPK and 15 tonnes of FYM per hectare or phosphor-compost 8 tonnes /ha produced optimum flower yield. In addition, Nethra (1996) found more plant height, number of leaves, number of flowers per plant and flower yield per hectare due to the application of vermicompost at 10 tonnes per hectare and recommended dose of NPK. In China aster, while working on integrated effects on crop. Haripriya and Sriramachandrasekharan (2002) found that application of FYM + mine soil at 1:2 ratio resulted in the better growth and yield of marigold as compared to leaf mould and pressmud, while Kumar et al., (2003) observed that application of half N,P + full K $+\mathrm{VAM}+$ phosphobectrium gave maximum plant growth and flower yield in China aster. Nandre et al., (2005) recorded maximum flower yield by the soil application trated with Azotobacter along with 75 per cent nitrogen. An experiment conducted by Mogal et al., (2006) who observed the best growth in China aster (Callistephus chinensis L.) while plants received FYM at 20 tonnes per hectare, Azotobacter and PSB at $3 \mathrm{~kg}$ per hectare and $100 \% \mathrm{~N}$ through urea. Smitha et al., (2006) also reported that FYM + Azotobacter + Phosphorus solubilizing bacteria +100 percent nitrogen produced maximum yield of flowers, with improved quality of flowers and vase life (11.23 days) in China aster. Another study carried out by Chaitra and Patil, (2007) on biofertilizers which were used in combination 
with VC and inorganic fertilizers. Findings revealed that application of Azospirillum. PSB, vermicompost and 50 per cent recommended NPK gave highest flower yield of $(11.71 \mathrm{t} / \mathrm{ha})$ with the maximum net returns per rupee invested (1:4.1). The results strongly endorses the integrative approaches for over all optimum growth and yield inoculation of Azospirillum and PSB, enhanced the cell division and enlargement and also produced growth hormones, which is possible reason for increased growth. The cultivar Kamini of China aster performed better even when recommended dose of fertilizer was reduced to 50 per cent and integrated with application of Azospirillum + PSB + Vermicompost as compared to 100 per cent of RDF (Patil et al., 2007). More ever, Kirar et al., (2009) found that application of $75 \%$ NPK + Vermicompost + Azotobactor + PSB gave better results followed by, under treatment $50 \%$ NPK + Vermi-compost + Azotobactor + PSB in china aster. Masaye and Rangwala (2009) reported that application of $200 \mathrm{~kg} \mathrm{~N}+100 \mathrm{~kg}$ $\mathrm{P}_{2} \mathrm{O}+50 \mathrm{~kg} \mathrm{~K} \mathrm{~K}_{2} \mathrm{O}$ and $\mathrm{FYM}$ at $5 \mathrm{t} / \mathrm{ha}$ as a basal dose improved flower quality of china aster var. Poornima Swathi (2009) revealed that growth parameters viz., plant height, number of branches per plant, plant spread, leaf area and total dry matter production were highest with the combined application of $5 \mathrm{t}$ ha-1 vermicompost, PSB and Azospirillum each at $5 \mathrm{~kg} \mathrm{ha}^{-1}$ along with 75 per cent recommended dose of fertilizers. Similarly, Sonawane et al., (2008) concluded that the application of nitrogen at $200 \mathrm{~kg} \mathrm{ha}^{-1}$, phosphorus at $75 \mathrm{~kg}$ ha- 1 and FYM at $10 \mathrm{tha}^{-1}$ was found efficient to achieve significantly maximum flower yield over other levels. The application of $\mathrm{N}$ at 200 $\mathrm{kg} / \mathrm{ha}$ through urea, $\mathrm{P}$ at $75 \mathrm{~kg} / \mathrm{ha}$ through single superphosphate and FYM at 10 t/ha with basal $50 \mathrm{~kg} \mathrm{~K} \mathrm{~K}_{2} \mathrm{O} \mathrm{kg} / \mathrm{ha}$ through MOP was found beneficial in increasing the growth parameters, flower yield and $\mathrm{N}, \mathrm{P}$ and $\mathrm{K}$ uptake by China aster. However, Laishram et al., (2010) found that the treatment of $22.5 \mathrm{~g}$ per $\mathrm{m}^{2}$ each of NPK + vermicompost $(1 \mathrm{~kg}$ per $\mathrm{m}^{2}$ ) + biofertilizes (Azotobacter + PSB + VAM) produced the maximum flower yield in China aster. Ravindra et al., (2013) reported that the application of one ton/acre vermicompost and PSB and Azospirillum each of $2 \mathrm{~kg} / \mathrm{acre}$ in China aster gave better results. Munikrishnappa and Chandrashekar (2014) concluded that the growth, flowering and quality of China aster is significantly influenced by application of major nutrients along with organic manures. Khanna et al., (2016) concluded that application of Farmyard manure + Forest Litter + PSB can be recommended for commercial cultivation of China aster cv. Kamini.

\section{Gladiolus}

While studying the effect of vermicompost and sewage sludge applications combined with NPK, Gangadharan and Gopinath (2000), reported that the combination of 10 tonnes vermicompost per hectare +80 per cent NPK in gladiolus cv. White Prosperity resulted in the maximum number of cormels per plant, whereas 5 tonnes sewage sludge per hectare + 80 per cent NPK and 10 tonnes vermicompost per hectare +60 per cent NPK gave more number of spikes per hectare. In another study carried out by Gangadharan and Gopinath (2000) who observed that in gladiolus cv. White Prosperity, the combination of vermicompost@10 tonnes per hectare + 80 per cent recommended NPK increased the plant height, number of leaves, leaf area, leaf area index, fresh weight of whole plant, length of spike, width of spike, length of rachis, number of florets per spike and diameter of corms, while Asrey et al., (2002) reported that organic amendments like vermicompost, FYM and cotton cake were effective in increasing the vase life of gladiolus cv. Traderhom as compared to the inorganic NPK fertilizers. More ever, Pimpini and Zanin (2002) also studied the effect of type of soil and fertilizers 
on gladiolus. They observed better spike length, number of florets per spike and corm production with the application of 50 tonnes/ha manure, $250 \mathrm{~kg} / \mathrm{ha}$ nitrogen, 125 $\mathrm{kg} / \mathrm{ha}$ phosphorus and $250 \mathrm{~kg} / \mathrm{ha}$ potassium. However, the best results were obtained in peat soil and the poorest in sandy soil. Another experiment was conducted by Godes (2005) on integrated effects of inorganic and organic nutrients in gladiolus. The findings revealed that days required for flowering, number of florets per spike, spikes ha-1 were found maximum with application of $80 \% \mathrm{RDF}$ with Vermicompost + Azotobacter + PSB. Similar results were reported by Godse et al., (2006) who observed that plants receiving vermicompost $8 \mathrm{t} \mathrm{ha}^{-1}+$ Azotobacter and PSB @ $25 \mathrm{~kg} \mathrm{ha}^{-1}$ each $+80 \%$ RDF significantly increased yield and quality attributes of gladiolus viz., number of spikes $\mathrm{ha}^{-1}$, length of spike and number of florets spike ${ }^{-1}$ when compared with RDF and other treatments. Sharma et al., (2008) observed that the application of recommended doses of NPK along with vermicompost and dual inoculation of Azotobacter and PSB in gladiolus gave minimum days to sprouting, maximum spike length and number of florets per spike. The maximum corms and cormels were also recorded from the same treatment, Dubey et al., (2009) reported that combined application of Azotobacter + PSB was found best for all growth and flowering characters in gladiolus. Ali et al., (2013) stated that the treatment containing Azospirillum had recorded maximum plant height, florets spike-1, Spike length, Florets fresh weight and earliest sprouting than other treatments in gladiolus. An experiment conducted on gladiolus cv. Pusa Srijana to study the economic fisibility of gladiolus under different treatments. The results revealed that the maximum vase life of spikes (10.3 day) was recorded with the application of pendimethalin $0.75 \mathrm{~kg} / \mathrm{ha}+$ metribuzin $0.3 \mathrm{~kg} / \mathrm{ha}$ pre-emergence as compared to control (7.3 day). The maximum yield of corms $89.48 \mathrm{q} / \mathrm{ha}$ and cormels and marketable spikes (1.43 lakh per ha), net profit (Rs. 3.48 lakh/ha) and benefit: cost ratio (1.99) was received with the application of metribuzin $0.4 \mathrm{~kg} / \mathrm{ha}$ pre-emergence + residue (dry grass 5.0 tonnes/ha) over control (Dhakar et al., 2013). Kumari et al., (2013) conducted an experiment to study the effect of integrated nutrient management on growth and floral parameters in gladiolus (Gladiolus hybridus L) cv. American Beauty. The results of the experiment revealed that among the different treatments, application of 75 per cent RDF + VC (3 t/ha) + VAM (10 kg/ha) + Azospirillum $(10 \mathrm{~kg} / \mathrm{ha})+$ Trichoderma harzianum (5 $\mathrm{kg} / \mathrm{ha}$ ) resulted in maximum plant height, number of leaves per plant, minimum number of days taken for spike emergence, number of days taken for first flower bud opening on a spike, maximum number of florets per spikes, spike length, and spike girth. However, Kumar et al., (2013) had conducted an experiment on integrated nutrient management in gladiolus. The findings revealed that the treatment $80 \%$ R.D. of NPK (96 kg N, $80 \mathrm{~kg} \mathrm{P}$ and $80 \mathrm{~kg}$ $\mathrm{K} / \mathrm{ha})+$ vermicompost $(128 \mathrm{q} / \mathrm{ha})+$ Azotobacter $(5.28 \mathrm{~kg} / \mathrm{ha})$ showed better response to plant height, number of leaves and other growth parameters. Singh et al., (2013) reported that the application of $75 \% \mathrm{RDF}+2$ Tonnes of Vermicompost + PSB, $(2.5 \mathrm{~kg} / \mathrm{ha})+$ Azatobactor, $\quad(2.5 \mathrm{~kg} / \mathrm{ha})] \quad$ significantly increased the maximum plant height, number of leaves per plant, length of longest leaf per plant, number of sprouts per plant. This treatment was also found better in respect of early flowering, days required for visibility of first spike, days required for opening of the first flower. Basoli et al., (2014) investigated the impact of integrated nutrient management on gladiolus cv. Novalux. The results revealed that application of 3/4th recommended dose of $\mathrm{N}, \mathrm{P}$ and $\mathrm{K}+$ Azotobacter $+\mathrm{PSB}+\mathrm{KSB}$ was found most effective in increased the weight of corm /plant, size of corm, available $\mathrm{N}$ and $\mathrm{K}$ content in soil. The number of florets 
opened per spike and available $\mathrm{P}$ content in soil were also recorded maximum with application of $1 / 2$ recommended dose of $\mathrm{N}, \mathrm{P}$ and $\mathrm{K}+$ Azotobacter $+\mathrm{PSB}+\mathrm{KSB}$. Whereas, 3/4th recommended dose of $\mathrm{N}, \mathrm{P}$ and $\mathrm{K}+$ Azotobacter + PSB resulted maximum number of corms and cormels /plant. Kumar, (2014) reported that application of $75 \% \mathrm{RDF}+25 \%$ $\mathrm{VC}+2.0 \mathrm{~g} /$ plant Azospirillum $+2.0 \mathrm{~g} / \mathrm{plant}$ $\mathrm{PSB}$, significantly induced earlier sprouting and increased the height of plant, number of leaves per plant and length of longest leaf per plant. However, plant recieved 50\% RDF+ $50 \% \mathrm{VC}+2.0 \mathrm{~g} /$ plant Azospirillum +2.0 $\mathrm{g} /$ plant PSB had significantly maximum diameter of leaf. Plants received 50\% RDF+ $50 \% \mathrm{VC}+2.0 \mathrm{~g} /$ plant Azospirillum +2.0 $\mathrm{g}$ /plant PSB had emerged earlier spike while minimum days required for opening of first flower on spike and maximum longevity of spike was observed in treatment when plants received $75 \% \mathrm{RDF}+25 \%$ Leaf Mould +2.0 g/plant Azospirillum . $2.0 \mathrm{~g} / \mathrm{plant}$ PSB.

In terms of vase life of cut flowers at room temperature, treatment $75 \% \mathrm{RDF}+25 \% \mathrm{VC}+$ $2.0 \mathrm{~g} / \mathrm{plant}$ Azospirillum $+2.0 \mathrm{~g} / \mathrm{plant}$ PSB shown maximum vase life. Singh et al., (2014) also further reported that the application of $75 \%$ RDF+ 2 Tonnes of Vermicompost + PSB, (2.5kg/ha) + Azatobactor, (2.5kg/ha flower and corm characters during the study. Chaudhary et al., (2016) studied the combined effect of integrated nutrient management on vegetative growth and flowering characters of gladiolus cv. Snow Princess with the application of Azospirillum, PSB, vermicompost and FYM with and without 100, 75 and 50\% recommended dose of NPK. The results showed that the application of integrated nutrients, i.e. 50\% RDF (60:40:40 $\mathrm{kg} / \mathrm{ha}$ NPK) +10 tonnes/ha each of FYM and vermicompost $+2 \mathrm{~g} /$ plant each of Azospirillum and PSB produced significantly increased maximum length of spike, number of florets per spike, duration of flowering and yield of corms. The dry weight of plant was also found maximum with the application of $75 \% \mathrm{RDF}+10$ tonnes/ha each of FYM and vermicompost +2 g/plant each of Azospirillum and PSB. Akter et al., (2017) observed significant variation in most of the parameters when organic manure, chemical fertilizer and bio-control agents were applied. The treatment containing poultry manure (5 t/ha) + Trichocompost (3 t/ha) +1/4 RDF had taken the minimum period (68 days) for $80 \%$ spike initiation while the maximum length of spike $(80.0 \mathrm{~cm})$ and rachis $(34.0 \mathrm{~cm})$, number of florets/spike (16), number of spikes/ha (200000) was registered with the plant recieving Vermicompost (5 t/ha) + Trichocompost (3t/ha) + 1/4 RDF. Khanam et al., (2017) obtained the maximum growth and quality parameters with integration of 50\% recommended dose of chemical fertilizers (RDF) with vermicompost @ 2.5 ton/ha.

Singh et al., (2014) inoculated the gladiolus corms with Azospirillum and VAM alone and in combination of nitrogen, phosphorus and potash including application of 10 tonnes FYM ha-1 in each treatment. Soil pH, electrical conductivity, organic carbon, available nitrogen, phosphorus and potash were estimated. Results revealed that lowest soil $\mathrm{pH}$ observed with Azospirillum $+50 \% \mathrm{~N}$ $+200 \mathrm{~kg} \mathrm{P}_{2} \mathrm{O}_{5}+200 \mathrm{~kg} \mathrm{~K}_{2} \mathrm{O}$ while lowest EC was recorded with Azospirillum $+75 \% \mathrm{~N}+$ $200 \mathrm{~kg} \mathrm{P}_{2} \mathrm{O}_{5}+200 \mathrm{~kg} \mathrm{~K} 2 \mathrm{O}$ being $0.57 \mathrm{dSm}-1$ and $0.51 \mathrm{dSm}-1$ respectively. The treatment combination i.e. (Azospirillum $+75 \% \mathrm{~N}+200$ $\mathrm{kg} \mathrm{P}_{2} \mathrm{O}_{5}+200 \mathrm{~kg} \mathrm{~K}_{2} \mathrm{O}$ ) when applied in gladiolus also showed highest available Nitrogen, phosphorus and potash in soil of field. The build-up of available N, P and K in soil and consequent higher plant leaf nutrients was also detected with $50 \%$ RDF + vermicompost @ 2.5 ton/ha. Sathyanarayana et al., (2017) stated that the application of 100\% RDF + FYM @ 7.5 t/ha + Azotobacter $+\mathrm{PSB}+\mathrm{KMB}+1 \%$ foliar spray of Nauroji 
Novel Organic Liquid Fertilizer significantly increased maximum growth, flowering and corm production in gladiolus.

\section{Tuberose}

In tuberose $\mathrm{Cv}$. Single, increased flower yield was obtained by inoculating Azotobacter and Azospirillum alone or in combination (Wange et al., 1995) while, Munikrishnappa et al., (2004) stated that the application of 50 per cent of recommended dose of fertilizer (RDF) along with vermicompost at 5 tonnes per hectare had improved the flower characters viz., spike length, rachis length, florets diameter, number of florets per spike and flower yield of tuberose. Padanagur et al., (2005) observed that plants which received vermicompost either alone or in combination with $1 / 2$ RDF had earlier flowering, while higher flower spike yield (1.12 and 1.16 lakh per hectare was obtained with the application of $3 \mathrm{~kg}$ vermicompost per square metre along with $50 \%$ recommended dose of fertilizers. Tripathi et al., (2012) found maximum spike yield, shoots per clump and number of leaves in tuberose when $75 \%$ recommended $100 \mathrm{~kg}$ NPK ha-1)+ 500q ha-1 FYM + 250q ha-1 VC were applied in tuberose. Hadwani et al., (2013) observed that application of FYM @ 30 t/ha + PSB @ 2g/m2 + Azotobacter@2 $\mathrm{g} / \mathrm{m}^{2}$ increased maximum length of spike, number of florets per spike, number of spike per plant, longest vase life and in situ longevity of spike were recorded in treatment 1/2 RDF + NC @ 1 t/ha + PSB @ 1g/m2 + Azotobacter@ $1 \mathrm{~g} / \mathrm{m}^{2}$. Kashyap et al., (2013) evaluated the effect of boifertilizers (Azotobacter, PSB) along with the chemical fertilizers $(\mathrm{N}, \mathrm{P}$ and $\mathrm{K})$ and a basal dose of FYM @ $5 \mathrm{~kg} / \mathrm{m}^{2}$ on growth and flowering in tuberose. The growth parameters (plant height, number of leaves per plant, days taken for emergence of bulbs) were increased significantly with the increasing levels of chemical fertilizers along with the boifertilizers applications while, Kumar, (2014) concluded that $75 \% \mathrm{RDF}+25 \% \mathrm{VC}+$ $2.0 \mathrm{~g} /$ plant Azospirillum $+2 \mathrm{~g} / \mathrm{plant}$ PSB, significantly induced earlier sprouting and also increased the height of plant, number of leaves per plant, length of longest leaf per plant and width of longest leaf. Results also showed significant variation among the treatments in terms of days required for visibility of first spike and opening of first flower on the spike. Kumar et al., (2015) concluded that $50 \% \mathrm{RDF}+50 \%$ vermicompost $+2 \mathrm{~g} /$ plant Azospirillum $+2 \mathrm{~g} /$ plant PSB produced maximum diameter of flower, number of flowers/spike, diameter of spikes/ bulb, while $75 \% \mathrm{RDF}+25 \% \mathrm{VC}+2 \mathrm{~g}$ each Azospirillum and PSB gave longer spike and maximum bulbs. Shirsat et al., (2015) recorded maximum number of spikes plant ${ }^{-1}$, plot $^{-1}$ and hectare ${ }^{-1}$, number of florets spike $^{-1}$ and total nutrient content (N, P and $\mathrm{K}$ ) in flower and plant with the application of $50 \% \mathrm{~N}$ through vermicompost $+50 \% \mathrm{~N}$ through urea $+\mathrm{P}$ and $\mathrm{K}$ (RDF) followed by application of $50 \% \mathrm{~N}$ through $\mathrm{FYM}+50 \% \mathrm{~N}$ through urea $+\mathrm{P}$ and $\mathrm{K}$ (RDF) and application of recommended dose of fertilizer.

\section{Marigold}

Gupta et al., (1999) observed that growth and flower yields were highest with Azotobacter + Phosphorus Solubilizing Bacteria (AZB + PSB) in combination of $75 \%$ to $100 \%$ nitrogen in marigold (Tagetes erecta L.). Various yield parameters of plant such as size of flowers, average weight of flowers, fresh weight of flowers per plant (flower yield), dry weight of flowers per plant and dry matter yield of plant were recorded. Application of vermicompost (15 tonnes per hectare) +100 per cent recommended NPK in marigold produced maximum number of flowers per plant with greater flower diameter and flower yield than plants received no vermicompost and fertilizer application (Mashaldi, 2000). 
Fig.1 The nutrient budgets between inputs and outputs, and the principles of INM method (Jat $e t$ al., 2015)

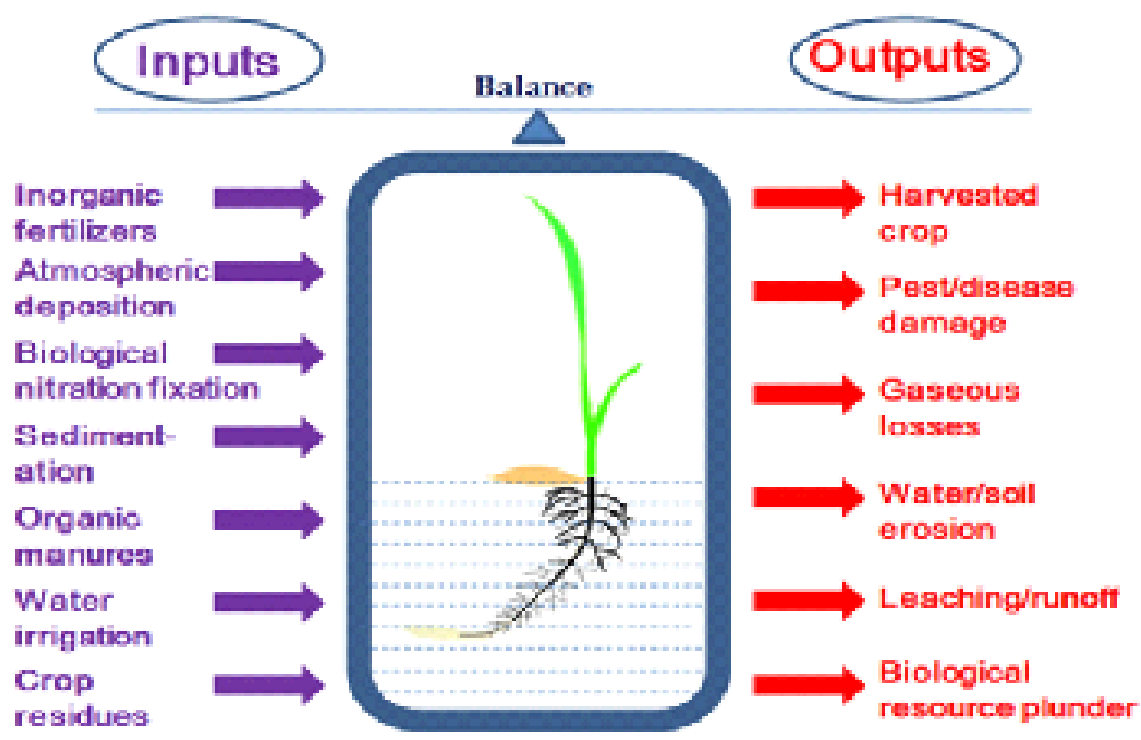

Fig.2 Global biofertilizers market revenue, 2012 - 2022 (USD Million)

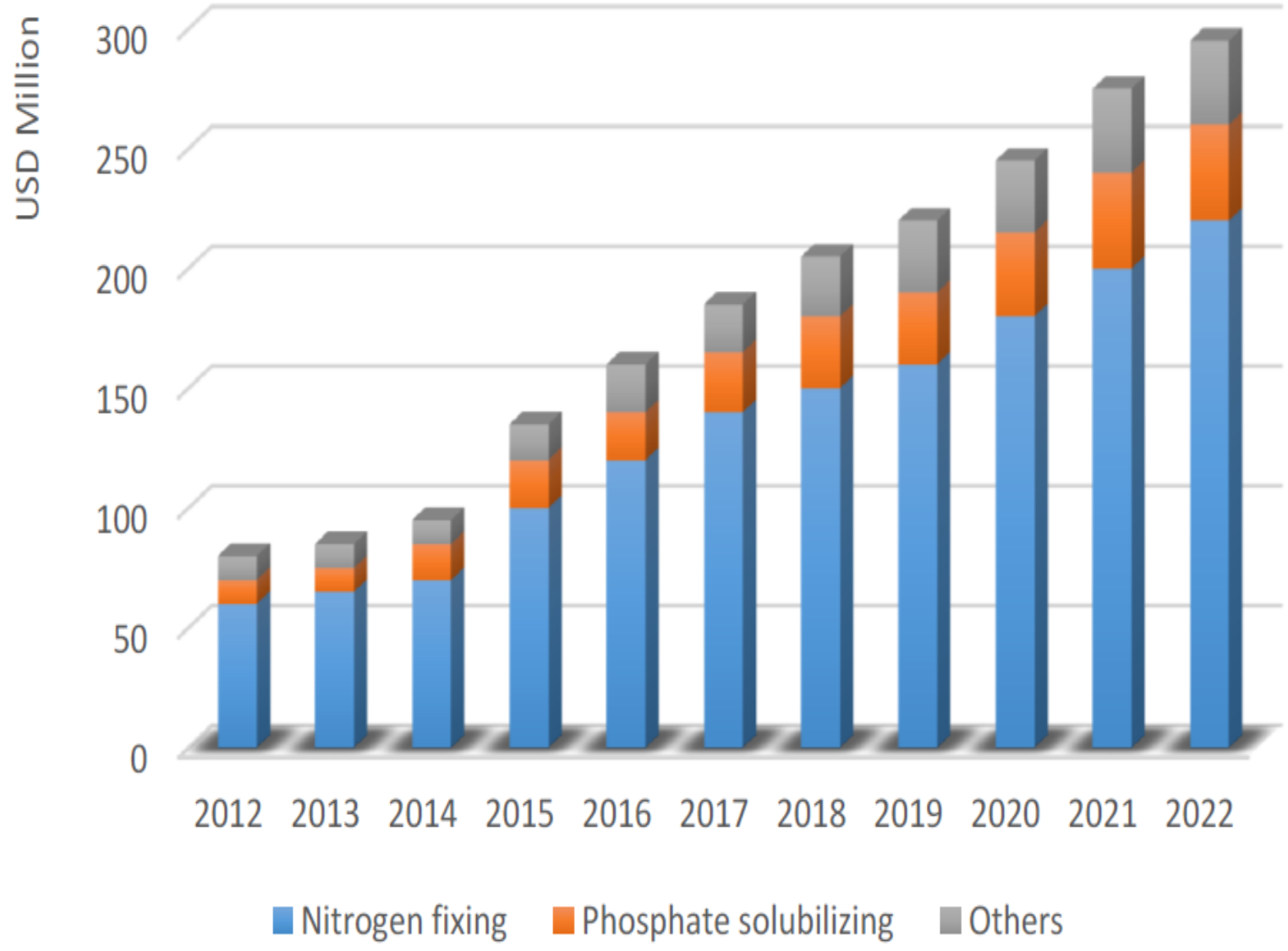


Fig.3 Production of Urea in India (in units of LMT)

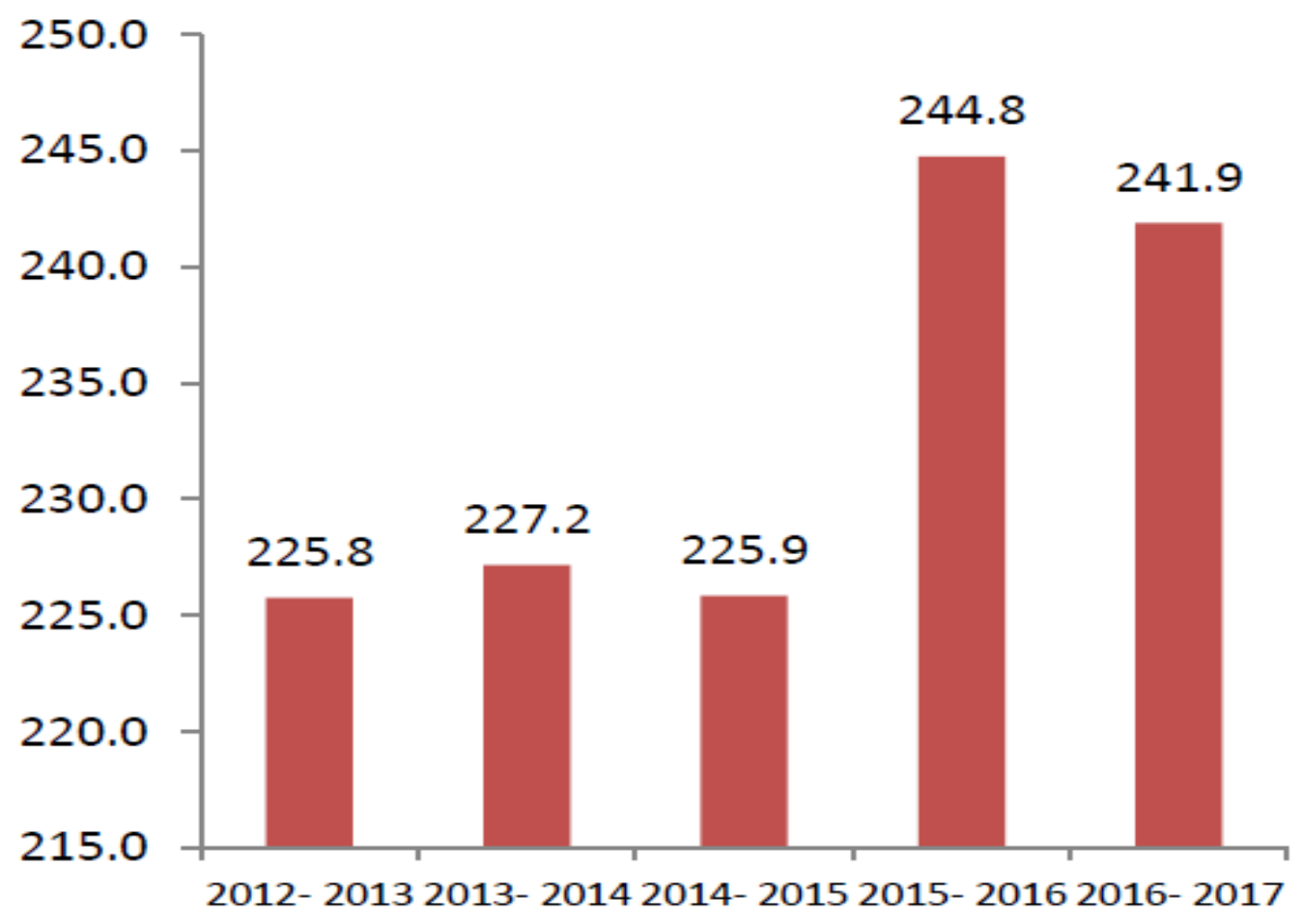

Fig.4 Urea Imports by India (in units of LMT)

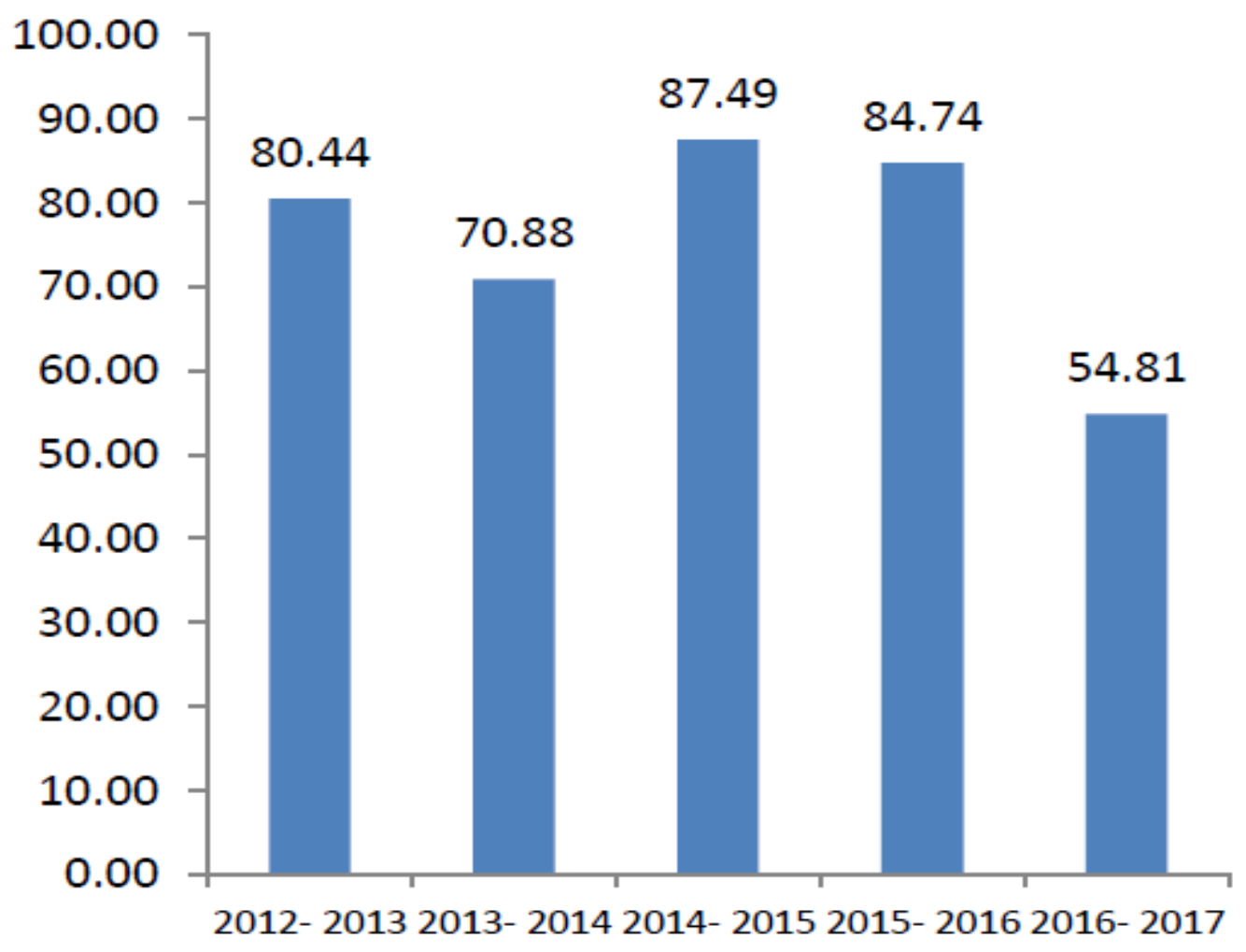


Fig.5 Production of DAP in India (in units of LMT)

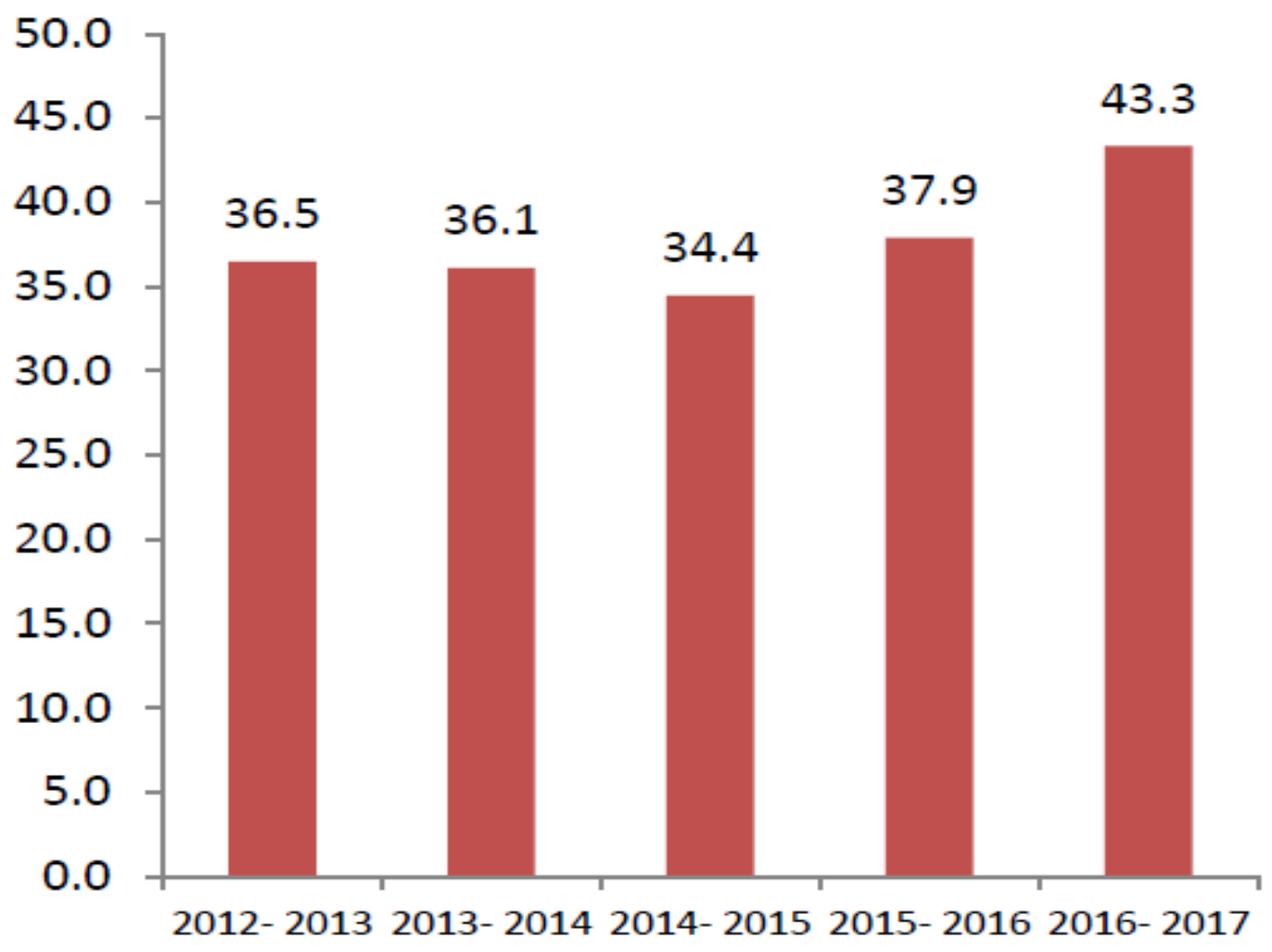

Fig.6 DAP imports by India (in units of LMT)

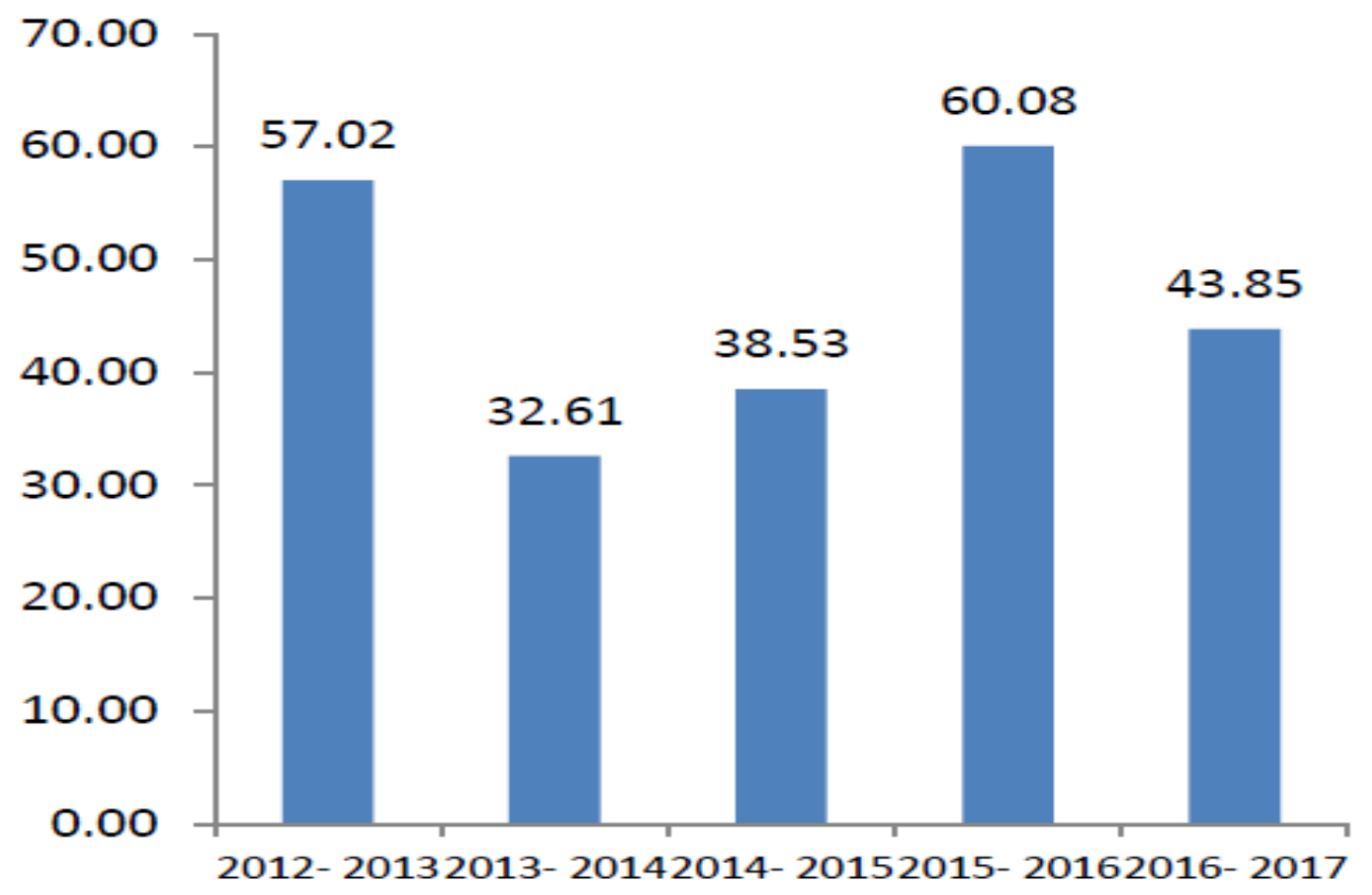


Fig.7 MOP imports by India (in units of LMT)

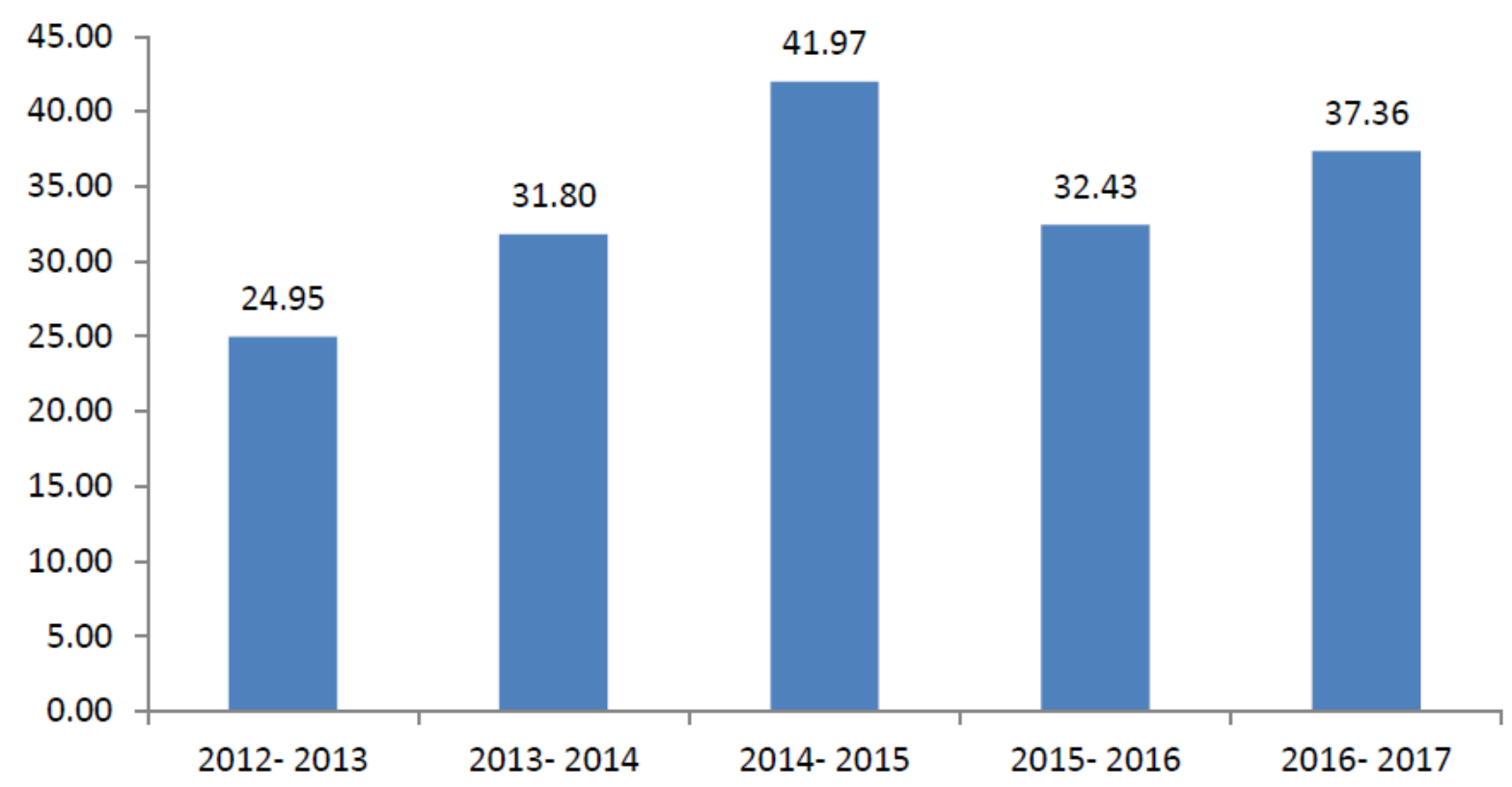

Atiyeh et al., (2000) found that relatively low concentration of vermicompost could promote plant growth in marigold. Rajadurai et al., (2000) reported that application of NPK @ $45: 45: 37.5 / \mathrm{kg}$ along with combined inoculation of Azospirillum and VAM exhibited increased growth in respect of plant height $(144.50 \mathrm{~cm})$ number of leaves $(156.20)$ and laterals per plant (28.30) in marigold. Yadav et al., (2000) observed the reduction in flower size, number of flowers per plant and flower yield) in African marigold at higher dose of $\mathrm{N}$ (>180ppm. The application of FYM improved the flower characters. Chauhan et al., (2005) studied the effect on application of vermicompost in marigold cv. Pusa Narangi Gainda. The findings revealed that application of vermicompost @ $1000 \mathrm{~g} / \mathrm{m} 2$ recorded higher yield of flowers $(1757.76 \mathrm{~g} / \mathrm{m} 2)$ compared to vermicompost @ $500 \mathrm{~g} / \mathrm{m} 2$ $(1429.00 \mathrm{~g} / \mathrm{m} 2)$. Shubha (2006) reported that in days to flower bud initiation and 50 per cent flowering in marigold cv. Orange Double with vermicompost + Poultry manure + Azospirillum +75 per cent recommended dose of nitrogen. Another study carried out to examine the effect of integrated nutrient management on carotenoid yield in African marigold. It was inferred that yield components like number of flowers per plant, flower yield and petal meal yield were maximum with treatment combination of vermicompost $(12.5 \% \mathrm{~N})+$ poultry manure $(12.5 \% \mathrm{~N})+$ Azospirillum along with 75 $\%$ RDN per hectare (Naik et al., 2008). Pushkar et al., (2008) found that soil application of VAM fungi @ $10 \mathrm{~kg}$ per hectare was most effective for floral characters and flower yield of African marigold. Similar results were observed by Kumar et al., (2009) when used the application of Azotobacter + PSB +FYM @ 30 tonnes per hectare $+\mathrm{N} @ 100 \mathrm{~kg}$ per hectare and P@50 kg per hectare and found to be the best for growth, flowering behaviour and yield of cv. African Giant double orange. Application of $50 \%$ NPK + FYM + vermicompost in African marigold cv. Pusa Narangi, recorded significantly higher plant height $(75 \mathrm{~cm})$, maximum number of branches (12.45), number of flower/plant (60), flower diameter $(9.40 \mathrm{~cm})$, flower 
weight $(7.85 \mathrm{~g})$ and flower yield per plant (471 g) compared to treatment when plants received $100 \%$ NPK + FYM + vermicompost (Bhat et al., 2010). However, Sangwan et al., (2010) worked on the effect of vermicompost with potting media on growth and flower yield in marigold. They observed that addition of vermicompost in appropriate quantities, to potting media has synergistic effects on flowering of plants including number of buds, number of flowers, and diameter of flowers. Maximum numbers of flowers was produced in the potting media containing $30 \%$ of vermicompost (common dose). The diameter of the biggest flower in marigold was reported in the potting media containing $40 \%$ of sugar mill waste water treatment plant sludge vermicompost. Singh et al., (2015) stated that plants gown in sand + soil + vermicompost $(1: 1: 2)+5 \%$ biodynamic amendment significantly gave maximum plant height $(27.750 \mathrm{~cm})$, plant spread $(23.175 \mathrm{~cm})$, number of branches per plant (25.454),stem diameter $(1.549 \mathrm{~cm})$, number of leaves per plant (140.714), leaf length $(9.308 \mathrm{~cm})$ and leaf width $(4.896 \mathrm{~cm})$. The same treatment was also found superior in terms of days to first flower bud initiation (24.22), flower bud diameter $(1.94 \mathrm{~cm})$, bud length $(3.49 \mathrm{~cm})$, number of flower per plant (16.27), and flower diameter $(7.98 \mathrm{~cm})$ over control. Singh et al., (2015) reported that the application 75 $\%$ recommended dose of NPK $(75 \mathrm{Kg} \mathrm{N}, 75$ $\mathrm{Kg} \quad \mathrm{P} 2 \mathrm{O} 5$ and $75 \quad \mathrm{Kg} \quad \mathrm{K} 2 \mathrm{O}$ ha-1)+ vermicompost $80 \mathrm{q}$ ha-1 + Azatobacter 3.3 $\mathrm{Kg}$ ha-1), gave maximum high of the plant $(94.84 \mathrm{~cm})$, plant spread $(49.41 \mathrm{~cm})$, leaf area $(49.46 \mathrm{~cm})$ number of branches $(15.92)$, total dry matter (39.03 g/plant), flower diameter $(6.7 \mathrm{~cm})$, weight of flower plant-1 $(45.97 \mathrm{~g})$, number of flower (58.32), per cent weight $(3.99 \mathrm{~g})$ and yield of flower plant-1 $(368.29 \mathrm{~g})$, yield of flower (26.48 tonne ha-1). The treatment was also found significantly most effective in inducing earliest flowering and duration of flowering. However, Sharma et al., (2017) worked on the effect of integrated nutrient management on marigold and concluded that the application of Azospirillum + Phosphate-Solubilizing Bacteria $+5 \%$ Cow Urine $+50 \%$ recommended dose of " $\mathrm{N}$ " through Vermicompost $+50 \%$ recommended dose of NPK fertilizer was most effective in increasing vegetative growth parameters, such as plant height, number of branches, plant spread, as well as flower yield parameters like number of flowers, flower diameter, fresh and dry weight of flowers, flower yield, flowering duration, shelf life, and it also had the maximum benefit:cost ratio was also calculated with the treatments. Another study carried out by Kumawat et al., (2017) who reported that the application of $75 \% \mathrm{RDF}+$ FYM @ $20 \mathrm{t}$ ha per ha along with inoculation of seedlings with Azotobacter + PSB produced higher plant height, number of primary branches on plant, weight of flower, number of flowers plant, yield of flowers plot as well as ha. These parameters were statistically at par with the application of $50 \%$ $\mathrm{RDF}+\mathrm{FYM} @ 20 \mathrm{t}$ hal along with inoculation of seedlings with Azotobacter + PSB.

\section{Gerbera}

Narayanagowda, (2003) recorded maximum flower yield, flower diameter and stalk length with treatment combination of vermicompost 15 tonnes per hectare and 75 per cent recommended NPK. Thane et al., (2007) reported that the application of $70 \%$ RFR + Azotobacter + PSB resulted in the greatest flower stalk length $(52.96 \mathrm{~cm})$, flower stalk diameter $(0.70 \mathrm{~cm})$, flower diameter $(9.20$ $\mathrm{cm})$ and number of flowers per plant (7.22) in Gerbera jamesonii. Gurav et al., (2008) reported that the plants treated with CBD + vermicompost @ 500g per $\mathrm{m}^{2}$ twice a year) + $3 \%$ panchagavya $+3 \%$ Manchurian tea had significantly maximum number of flowers per plant (35.4), lower stalk length (50.8), flower 
stalk diameter (6.78) and vase life (5.5days). However, Sindhu et al., (2009) worked on the effect of nutrient management on soil quality and productivity in gerbera. The findings revealed that the highest bulk density $(0.58$ $\mathrm{g} / \mathrm{cm} 3)$ and electric conductivity $(0.85 \mathrm{dS} / \mathrm{m})$ were recorded in media when amended with soil + farmyard manure + vermicompost + samridhi + sawdust. The maximum leaf magnesium content $(0.55 \%)$ was recorded in the plants grown in media amended with vermicompost.

\section{Carnation}

Carnation cv. Raggio-desole produced maximum plant height number of flowers, length of stalk, flower size, earliness in flowering, highest vase life when grown in a culture having soil + sand + Vermicompost $(1: 1: 1) \quad(\mathrm{v} / \mathrm{v}+$ inorganic fertilizer + Bio fertilizer (Azospirillum and PSB) compared to treatments having FYM and municipal compost in the place of vermicompost (Bhalla et al., 2007). Swamy (2010) observed that carnation cv. Dona recorded maximum plant growth, flower quality and yield when plants are supplied with 50 per cent RDF + Vermicompost +3 per cent Manchurian tea + 3 per cent Panchagavya. Least number of flowers per plant and flowers per square meter were recorded in plants receiving common basal dose $(8.00$ and 160.00 respectively). Sharma et al., (2010) stated that carnation plants supplied with common basal dose along with biofertilizers (Azospirillum, PSB, VAM and Trichoderma @ 2g/plant) + 6\% Panchagavya and 6\% Manchurian mushroom tea showed highest plant height $(71.03 \mathrm{~cm})$, stem length $(64.77 \mathrm{~cm})$, flower size $(4.99 \mathrm{~cm})$ and Number of flowers (6.60/plant). Singh et al., (2010) observed that the treatment $75 \%$ RDF + FYM $1 \mathrm{~kg}$ per $\mathrm{m} 2$ per year + vermicompost $300 \mathrm{~g}$ per plant per year + Azospirillum + PSB 2 g produced the maximum number of flowers per plant (6.3), flower stem length $(67.40 \mathrm{~cm})$ and flower per square meter (125.67) in carnation.

\section{Chrysanthemum}

Chrysanthemum flower yield increased from 10.79 to 16.85 tonnes per hectare, when the plots received $\mathrm{N}, \mathrm{P}_{2} \mathrm{O}_{5}$ and $\mathrm{K}_{2} \mathrm{O}$ at the rate of 20:20:20 g + 5 kg FYM per sq. m (Chezhiyan et al., 1986) while, Verma et al., (2011) reported that the use of Azospirillum, PSB, vermicompost equivalent $50 \%$ RD'N', 50 per cent FYM along with 50 per cent recommended nitrogen, phosphorus and potassium helped in realizing better plant growth, flower yield and better quality of flowers and higher benefit cost ratio under field condition in chrysanthemum (Chrysanthemum morifolium Ramat.) $\mathrm{Cv}$. Raja. Pandey et al., (2010) studied the influence of bio-inoculant (Azotobacter and VAM) and vermicompost with different levels of nitrogen, phosphorus and potassium $(100 \%, 75 \%$ and $50 \%)$ on growth and flowering of chrysanthemum cultivars 'Prof. Harris' and 'Sunil'. Application of $75 \%$ recommended dose of fertilizer and vermicompost coupled with dual inoculation of Azotobacter and VAM produced significantly maximum plant, higher number of lateral shoots, plant spread, advancement in visible bud formation, bud showing colour and flowering respectively. Extension of flowering duration was recorded with $100 \%$ recommended dose of fertilizer. Maximum number of leaves were recorded with $75 \%$ dose of $\mathrm{N}+$ Azotobacter+ VAM + full $\mathrm{P}$ and $\mathrm{K}$ while, higher leaf area was observed when crop was fertilized with $75 \%$ dose of $\mathrm{N}$ and $\mathrm{P}+$ Azotobacter + VAM + full $\mathrm{K}$ as compared with $100 \%$ recommended dose of fertilize. However, Kumar, (2015) studied the effect of integrated nutrient management on growth and flowering in chrysanthemum. The results revealed that the application of $75 \% \mathrm{RDF}+$ $25 \% \mathrm{VC}+2.0 \mathrm{~g} / \mathrm{plant}$ Azospirillum $+2.0 \mathrm{~g} /$ 
plant PSB significantly induced the days taken to sprouting and produced maximum plant height, number of leaves per plant and length of longest leaf. However, treatment received 50\% $\mathrm{RDF}+50 \%$ Leaf Manure + 2g/plant Azospirillum $+2 \mathrm{~g} /$ plant PSB had maximum diameter of leaf. The treatment receiving $50 \% \mathrm{RDF}+50 \% \mathrm{VC}+2.0 \mathrm{~g} / \mathrm{plant}$ Azospirillum + $2.0 \mathrm{~g} / \mathrm{plant}$ PSB emerged earlier spike while minimum days required for opening of first flower on spike and maximum longevity of spike was observed in treatment where plants recieved $75 \% \mathrm{RDF}+$ $25 \% \mathrm{VC}+2 \mathrm{~g} /$ plant Azospirillum $+2 \mathrm{~g} /$ plant PSB. In terms of vase life of cut flowers at room temperature, the treatment receiving $75 \%$ RDF $+25 \%$ Leaf Manure shown maximum vase life. Mahadik et al., (2017) recorded the maximum plant height, number of branches per plant, minimum days to first flower bud initiation, opening of flower and $50 \%$ flowering, maximum flower heads plant1, flower yield per plant, diameter and shelf life of the flower when plants were received biofertilizers and 50\% RDF $(15: 100: 100 \mathrm{~kg}$ per ha of NPK $)+10 \mathrm{t}$ per ha $\mathrm{VC}(50 \% \mathrm{~N}$ through VC).

\section{Dahlia}

Ahmed et al., (2004) reported that application of Urea, $\mathrm{P}_{2} \mathrm{O}_{5}$ and $\mathrm{FYM}$ in different combinations significant reduced early flowering and increased number of flowers per plant and vase life as compared to other doses of fertilizers. Size of flowers were increased by the application of urea with combination of potash and FYM and also by using single $\mathrm{P}_{2} \mathrm{O}_{5}$ while single FYM and urea did not affect size of flowers in dahlia. While, Pandey et al., (2017) worked on the effect vermicompost and biofertilizers on growth and flowering on dahlia. The findings revealed the maximum plant height (65.07 $\mathrm{cm}$ ), number of primary branches (9.67), number of leaves (33.67), plant spread
$(43.73 \mathrm{~cm})$, number of flowers $(8.13)$, duration of flowering (10.53), flower yield ha 1(33.65), weight of tuber ( $56.67 \mathrm{~g})$, number of tubers (4.87) and tuber yield (13.80 $\left.\mathrm{t} \mathrm{ha}^{-1}\right)$ when plants received the Vermicompost@ 2.5 t per ha + Azotobacter @ 2.0 kg per ha + Phosphorous Solubilizing Bacteria@2.0 kg per ha.

\section{Rose}

Choudhury et al., (2009) observed that the application of $50 \mathrm{~g} \mathrm{~N}$ per plant + Azotobacter and Azospirillum each @ 1ml per plant produced maximum diameter of flower, number of petals, weight of individual flower, shelf life and yield of flowers as compared to control. Application of $25 \mathrm{~g} \mathrm{~N}$ per plant Azotobacter and Azospirillum each @ 1ml per plant produced maximum initiation of first flower in rose (Rosa damascena L.) than control.

\section{Other floricultural crops}

Reduction in the fertilizer levels were made up with the vermicompost application without any loss of yield owing to higher $\mathrm{P}$ mineralization due to symbiotic mycorrhizal association in salvia and ornamental plants Kale et al., (1987). The significant increase in the leaf area index and flowering was also observed due to vermicompost application. Ravichandran (1991) reported improved flower yield, flower diameter and weight in Crossandra infundibuliformis, with Azospirillum + recommended dose of nitrogen. However, Bhavanisanker and Vangamudi, (1999) reported that combined application of 100 per cent nitrogen as urea and Azospirillum showed maximum length of spike $(3.53 \mathrm{~cm})$ and number of flowers per spike (5.66) in Crossandra. Another experiment conducted by Bhavanishankar and Vanangamudi, (1999) who reported that the combined application of 75 per cent 
recommended $\mathrm{N}$ as neem cake blended urea + Azospirillum recorded the highest flower yield in Jasminum sambac (1.560, 1.739 and 1.779 $\mathrm{kg}$ per plant, respectively after 1, 2 and 3 years fertilizer application and 1 and 2 years of fertilizer application (1.445 and $1.607 \mathrm{~kg}$ per plant, respectively). The golden rod plants supplied with vermicompost (10 tonnes per hectare) and 100 per cent recommended NPK $(100: 50: 50 \mathrm{~kg} / \mathrm{ha})$ produced greater plant height, maximum number of leaves and highest flower yield (Kusuma, 2001). Narasimha Raju and Haripriya, (2001) noticed maximum plant height, higher number of branches, dry matter and increased flower yield in crossandra by the application of Azospirillum and phosphobacteria in combination with 100 per cent of NPK (75:50:125 kg ha ${ }^{-1}$ ). Padmadevi et al., (2001) observed highest vase life in Anthurium when plants were treated with Azospirillum, phosphobacteria, VAM along with inorganic nutrients and growth regulators. Gayithri et $a l .$, (2004) conducted an experiment on statice and observed that flower components were significantly increased by application of $75 \%$ recommended dose of $\mathrm{N}$ and $\mathrm{P}+100 \% \mathrm{~K}+$ Vermicompost + Azotobacter + PSB and was at par with $50 \% \mathrm{~N}$ and $\mathrm{P}+100 \% \mathrm{~K}+$ Vermicompost + Azotobacter + PSB in respect of spike emergence, initiation of flowers, flower harvesting, spike length, spread and number of branches per spike. Prakash et al., (2002) stated that phosphorous and potassium content in the leaves increased with addition of 5 and 10 per cent FYM whereas, $\mathrm{N}$ content was increased in the leaves only with addition of 5 per cent FYM. Addition of FYM to the soil also increased the yield parameters in their study. Jawaharlal and Padmadevi (2003) noticed that the application of biofertilizers along with inorganic nutrients and growth regulators had significant effect on growth and flowering in anthurium. While, Gayathri et al., (2004) when working with combined use of inorganic, biofertilizers and organic manures and observed that the application of 75 per cent NP + 100 per cent K + VC + Azotobacter + PSB significantly increased plant height, number of leaves, number of branches and highest flower yield per plant in statice. Singh and Rathore (2004) recorded highest number of spikes and flower yield per hectare with NPK $(120+60+40 \mathrm{~kg}$ per hectare $)+$ FYM 10 tonnes per hectare $+\mathrm{ZnSO}_{4} 25 \mathrm{~kg}$ per hectare. While working with organic sources of nutrients i.e. panchagavya in combined with traditional organic and inorganic sources, Mohd et al., (2006) reported that the combination of panchagavya $4 \%+50 \%$ recommended dose of fertilizers (RDF) increased the spathe length $(32.10 \mathrm{~cm})$ while the combination of vermicompost $100 \mathrm{~g}$ per plant $+50 \%$ RDF recorded the highest value of inflorescence longevity (88.30 days), number of days for exhibiting flowers loss, spathe blueing and spadic necrosis. An experiment was carried out by Jhon et al., (2007) to assessed the interaction impact of organic manure and inorganic fertiliser ( $\mathrm{M} \mathrm{x}$ F) on growth and bulb production in tulip cv. Apeldoorn. The results revealed that the interaction of organic manure and mineral fertility levels showed significant effect on plant height, wrapper leaf area, number of bulbs and their weight, large sized bulbs, number of bulblets and their weight $\mathrm{m}^{-}{ }^{2}$,. The findings also demonstrated that organic manure (60 tonnes ha-1) in conjugation with inorganic fertilizers (N 75 P $30 \mathrm{~K} 30 \mathrm{~kg} / \mathrm{ha}$ ) improved plant height, wrapper leaf area, total number of bulbs/m, large sized bulbs and number of bulblets $/ \mathrm{m}^{2}$. However, Chamani et al., (2008) observed that increasing the vermicompost content in the base media decreased flower numbers in petunia. Jayamma et al., (2008) observed that the biofertilizes application could substitute the recommended NPK fertilizers to the extent of $50 \%$ without affecting various floral characteristics and flower yield in jasmine 
(Jasminum sambac). Anburani et al., (2008) studied the influence of various organic manures (FYM @ 25 tonnes per hectare and neem cake@ 5 tonnes per hectare) combined with graded levels of inorganic fertilizers $(75,100$ and $125 \%$ of RDF) and with two levels of vermiwash on growth attributes of jasmine. Application of neem cake @ 5 tonnes hectare combined with $125 \%$ of RDF (150:300:300g per plant) and vermiwash application increased the plant height, number of leaves per primary shoot and leaf area per plant. the application of 75 per cent NP +100 per cent $\mathrm{K}+\mathrm{VC}+$ Azotobacter $+\mathrm{PSB}$ while Naik et al., (2009) reported that application of NPK with Azospirillum, phosphobacteria each at $2 \mathrm{~g} / \mathrm{plant}$ significantly increased the number of leaves, flowers, leaf area and early flowering in anthurium. Sowmyamala et al., (2009) working on the effect of different sources of nutrient on growth and yield of gaillardia who observed that the application of $100 \%$ recommended doses of NPK + pressmud at 10 tonnes per hectare produced maximum diameter of flowers $(6.7 \mathrm{~cm})$, duration of flowering in plants and plots (131.66 and 140 days respectively) and also increased maximum flower yield per plant, per plot and per hectare $236 \mathrm{~g}$ and $4720 \mathrm{~g}$ and 29.13 tonnes respectively in gaillardia. Use of sand and FYM (1:1) produced maximum plant height, number of sprouts per plant, number of leaves per plant, diameter of shoot and number of flowers plant in wax Begonia (Anil et al., 2009). In Anthurium cv. Verdun Red, produced maximum leaf length $(38.00$ $\mathrm{cm})$, leaf width $(17.2 \mathrm{~cm})$, petiole length $(49.4$ $\mathrm{cm})$, petiole girth $(2.11 \mathrm{~cm})$, number of suckers (5) and all the economic traits i.e., floral parameters viz., early flowering (152.3 days) and number of spikes (9.4), spathe length $(12.1 \mathrm{~cm})$, spathe width $(8.7 \mathrm{~cm})$, spadix length $(7.5 \mathrm{~cm})$, stalk length $(53.5 \mathrm{~cm})$, girth of stalk $(1.9 \mathrm{~cm})$, longevity of spike on plant (21.0 days), days to loss of lustre (16 days), days to spathe blueing (18 days) and days to spadix necrosis (19 days) with applying common basal dose $+3 \%$ vermiwash. The plants received a common basal dose (CBD) with FYM 200 g/pot + decomposed coir compost 100 g/pot + vermicompost $25 \mathrm{~g} /$ pot + Biofertilizers (VAM + Azospirillum + PSB) @2 g each/pot and Trichoderma viridae $20 \mathrm{~g} / \mathrm{pot}$ at an interval of two months (Nagalakshmi, 2010). Parya et al., (2010) observed maximum plant height, number of leaf, suckers and number of flower stalk per plant in golden rod (Soildago canadensis) when plants treated with reduced level of chemical fertilizer ( $75 \%$ of RDF) along with $3 \mathrm{t} /$ ha of vermicompost, which was at par with treatment receiving $75 \%$ of RDF in conjunction with 3 t/ha of FYM. The findings also revealed that in presence of organic manure even at lower level $1.5 \mathrm{t} / \mathrm{ha}$ along with $75 \%$ RDF showed statistically similar response that to of $100 \%$ RDF. However, Gayathiri and Anburani, (2011) observed the combination of FYM @ 25 tha1 , consortium biofertilizer (2 $\mathrm{kg}$ ha-1) along with the recommended dose of inorganic fertilizers@ 112.5:37.5: 56.25 kg NPK ha-1 gave good results as compared to the other treatments in glory lilly. Deivasigamani and Thanunathan, (2011) worked on the effect of enriched FYM on growth and flowering on lily. The results demonstrated that the application of Enriched FYM at $750 \mathrm{~kg} \mathrm{ha}^{-1}$ had highest yield attributes like number of capsules plant $^{-1}$, number of seeds capsule ${ }^{-1}$, test weight $(\mathrm{g})$, seed yield and tuber yield in glory lilly. Moghadam et al., (2012) observed that the plants of $\mathrm{cv}$. Novona treated with $30 \%$ vermicompost had maximum number number of leaves, stem height and diameter and increased $\mathrm{GA}_{3}$ content in roots of lilium. Mousavi and Ordebili (2014) observed increased proline, soluble carbohydrate, $\mathrm{K}$, and $\mathrm{Ca}$ contents in leaf and root tissues of lilium plants when plants received vermicompost + sugarcane bagasse sewagesludge based compost. The combination of 
organic fertilizer along with inorganic fertilizer had beneficial for the photosynthetic activity and productivity of tea. Bioinoculants (BF) and/or inorganic fertilisers (IOF) were applied to assess the growth and development of nursery grown BSS (biclonal seed stocks) seedling. The findings revealed that during the first six months period, the recommended dosage of inorganic fertilizers with bio inoculants provided significantly higher values of biometric characteristics in terms of stem diameter, number of leaves, biomass production followed by the $100 \%$ recommended practice of IOF and 50\% IOF + BF. After 12 months, it was noticed that 100 $\%$ IOF had an edge over the other treatments followed by $50 \% \mathrm{IOF}+\mathrm{BF}$ in most of the biometric parameters (Balamurugan et al., 2013).

Kumar et al., (2015) observed the highest photosynthetic rate $(\mathrm{PN})$ with 45: $22.5: 45 \mathrm{~kg}$ ha basal through Urea, RP, MOP + vermicompost 50\%, followed by, 90: 45: 90 kg-ha basal through Urea, RP and MOP but the lowest values of these characters with the application of FYM @ 15 tones-ha. The application of $75 \%$ of NPK 90:38:56 kg ha-1 along with FYM @ 12.5 t ha-1 and vermicompost@5 t ha-1 was found to be superior in improving the growth and yield characters like plant height, number of branches, number of leaves, number of flowers, number of pods, pod yield per plant, pod yield per plot, seed yield per plant and estimated seed yield per hectare in glory lily (Sivasankar and Manivannan, 2015). Anand, et al., (2016) revealed that that application of common basal dose (N:P:K 30:10:10) + FYM $1.0 \mathrm{Kg}$ per pot + Decomposed Coir Compost $100 \mathrm{~g}$ per pot + Biofertilizers (VAM + Azospirillum + Trichoderma viride $20 \mathrm{~g}$ per pot) $+3 \%$ Panchakavya $+3 \%$ Manchurian tea produced maximum plant height, number of leaves per plant in Cymbidium giganteum. One-year-old Bird-of-Paradise plants were supplied with different combinations of organic and inorganic nutrient sources. The findings revealed that maximum height of the plant, maximum leaf length, leaf width, number of leaves, number of suckers and plant spread were recorded when plants received 80 per cent RDF through fertigation plus organic source of nutrients like Vermicompost (300g) along with different biofertilizers such as Azotobacter, PSB and $\mathrm{KMB}$ as compared in plants received 100 per cent RDF as normal fertilizers through soil application Yathindra et al., (2016). Petunia plants produced the maximum plant height $(25.20 \mathrm{~cm})$, plant spread $(43.43 \mathrm{~cm})$, number of branches per plant (17.66), number of leaves per plant (300.30), yield of flower per plant (81.30 gm), yield of flower per plot (731.76 gm), flower yield per hectare (4.32 t/ha) and the maximum benefit - cost ratio $(1: 2.46)$ when plants were treated with Azotobactor + PSB +PMB + N120:P90:K60 (Kumari and Prasad, 2017).

In summery the growth, flowering and yield attributing characters of floricultural crops was significantly increased with the combined use of inorganic, organic and biofertilizers than the control and recommended doses of inorganic fertilizers. This increase was appear due to proper and judious uses of inorganic and organic sources of nutrients which resulted in supply of NPK and essential micronutrients on larger quantity to plants. So a judicial combination of inorganics and biofertilizers will give the best result on yields and its attributing characters in floricultural crops.

The above results showed that the pure chemical or pure organic treatments could not result in highest yield and quality. The integration of organic, biofertilizers along with chemical fertilizers has a positive effect on the growth, flowering and yield of floricultural crops and gives highest net 
returns and also increasing soil fertility status in harvested flower crops.

\section{References}

Ahmed, G. S., Neelofar and Khan, F.U. 2004. Vegetative growth of dahlia (Dahlia variablis Desf.) cv. Pink Attraction as affected by N, P and biofertilizers. In Book of abstracts. National Symposium on lifestyle floriculture: Challenges and Opportunities, March, 19-21.

Akter, N., Ara, K. A., Akand, M. H. and Alam, M. K. 2017. Vermicompost and trichocompost in combination with inorganic fertilizers increased growth, flowering and yield of Gladiolus cultivar (GL-031) (Gladiolus grandiflorus L.). Advances in Research, 12(3): 1-11

Ali, A., Mehmood, T., Hussain, R., Muhammad, B., Raza, S., Najam-Ud-Din, and Ahmad, A. 2013. Investigation of biofertilizers influence on vegetative growth, flower quality, bulb yield and nutrient uptake in gladiolus (Gladiolus grandiflorus L.). International Journal of Plant, Animal and Environmental Sciences, 4. 94-99.

Anand, M., Sankari, A., and Arulmozhiyan, A. 2016. Studies on the effect of integrated nutrient management in Cymbidium giganteum under shevaroy condition. The Bioscane. 11(1): 439443.

Anburani, A. and Vidhyapriyadharshini, H. 2008. Response of growth attributes of mullai (Jasminum auriculatum) to organic and inorganic nutrients. Journal of Ornamental Horticulture. 11 (3):212-215

Anil, K.S., Gupta, S. and Singh, A.K. 2009. Influence of various potting media on vegetative and root characteristics in wax begonia. Journal of Ornamental Horticulture, 12 (2): 111-115

Asrey R, Singh, R. and Kumar, S. 2002. Influence of organic manure and flower preservative on postharvest life of gladiolus cut flowers. Annals of Agricultural Research, 23(4): 659-663

Atiyeh, R.M., Edwads, C.A., Subler, S. and Metzer, J.D. 2000. Earthworm processed organic wastes as components of horticultural potting media for growing marigold and vegetable seedlings. Compost Science and Utilization, 8: 215-233.

Balamurugan, A. Jayanthi, R. Muthukannan, P. Sanmugapriyan, R. Kuberan, T. and Premkumar, R. 2013. Integrated nutrient management by using bioinoculants in seedlings of tea (Camellia sinensis) under nursery. International Journal of Advancements in Research \& Technology, 2(12): 2278-7763
Barman, M., Paul, S., Guha, A., Choudhury, P.R. and Sen, J. 2017. Biofertilizer as prospective input for sustainable agriculture in India. Int.J.Curr.Microbiol.App.Sci. 6(11): 1177-1186. doi: https://doi.org/10.20546/ijcmas.2017.611.141

Basoli, M., Kumar, P., Kumar, S. 2014. Impact of integrated nutrient management on post- harvest and corm characters of gladiolus cv. Novalux. Annual of Horticulture, 7(2): 109-114.

Bhalla, R., Shivakumar, M.H. and Jain, R. 2007. Effect of organic manures and biofertilizers on growth and flowering in Standard carnation. Journal of Ornamental Horticulture, 10 (4): 229-234

Bhat, D.J., Pandey, R.K., Sharma, J.P. and Shivani, J. 2010. Influence of integrated nutrient management on growth, flowering and yield of African marigold cv. Pusa Narangi. Environment and Ecology. 28 (1), 466-468.

Bhavanisankar, K. and Vanangamudi, K. 1999. Integrated nutrient management in gundmalli (Jasminum sabac L.). South Indian Horticulture Science. 47:111-114

Bhavanisanker, K. and Vanangamudi, K., 1990. Integrated nutrient management in gundumalli (Jasminum sambac L.). South Indian Horticulture, 47 (1-6): 111-114

Bhavanishanker, K. and Vanangamudi, K. 1999. Integrated nutrient management in Crossandra. South Indian Horticulture, 49 (1-6): 112-115.

Biofertilizers Market Analysis by Product (Nitrogen Fixation, Phosphate Solubilizing), by application (Seed Treatment, Soil Treatment) and Segment Forecasts to 2022. Grand View Research, San Francisco, USA

Chaitra, R. and Patil, V.S. (2007) Integrated nutrient management studies in China aster (Callistephus chinensis (L.) Nees). Karnataka J. Agric. Sci., 20(3): 689-690

Chamani, E., Joyce, D. C. and Reihanytabar, A. 2008. Vermicompost effects on the growth and flowering of Petunia hybrida Dream Neon Rose. American-Eurasian Journal Agriculture and Environmental Science, 3 (3): 506 - 512

Chandra, K. 2005. Organic manures. Regional Centre of Organic Farming No. 34, 5th Main Road Hebbal, Banglaore. Pp. 46.

Chaudhary, N., Swaroop, K., Janakiram, T., Biswas, D.R. and Singh, G. 2016. Effect of integrated nutrient management on vegetative growth and flowering characters of gladiolus. Indian J. Hort. 70(1): 156-159

Chauhan, S., Singh, C.N. and Singh, A.K. 2005. Effect of vermicompost and pinching on growth and flowering in marigold cv. Pusa Narangi Gianda. Progressive Horticulture, 37 (2): 419-422. 
Cheziyan, N., Nanjan, K. and Abdul Khader, J.B.M., 1986. Studies on the nutrient requirement of Chrysanthemum indicum cv. CO-1. South Indian Horticulture, 34 (3): 173-178.

Choudhari, C. K., Jadav, R. G. and Masu, M.M. 2009. Effect of biofertilizers and their combinations with nitrogen fertilizer on growth, yield and quality of rose (Rosa damascena L.). Asian Journal of Horticulture. 4 (2): 373 - 376

Deivasigamani, S. and Thanunathan, K. 2011. Integrated nutrient management practices for glori lily (Gloriosa superba 1.). Open Access Journal of Medicinal and Aromatic Plants. 2(1): 6-9.

Dhakar, S., Swaroop, K., Singh, K.P., Das, T.K., Kumar, P and Singh, N. 2016. Integrated weed management practices in gladiolus and their effect on flowering, weed density and corm yield Indian J. Hort. 73(4): 570-575

Dikr, W. and Belete, K. 2017. Review on the effect of organic fertilizers, biofertilizers and inorganic fertilizers (NPK) on growth and flower yield of marigold (Targets' erecta L.). Acad. Res. J. Agri. Sci. Res., 5 (3): 192-204

Dubey, R.K., Misra, R.L. and Singh, S.K. 2009. Studies of bio- and chemical fertilizers on certain floral qualities of gladiolus. "National Conference on Floriculture for Livelihood and Profitability" held on 16-19 March, 2009 at IARI, New Delhi, organized by ISOH, New Delhi, pp. 87

Edwards, C.A.R., Lal, P., Madden, R.H. Miller, G. House, G. eds. 1990. Sustainable Agricultural Systems. Ankeny, Iowa: Soil and Water Conservation Society, Iowa

Gangadharan, G. D. and Gopinath, G. (2000) Effect of organic and inorganic fertilizers on growth, flowering and quality of gladiolus cv. White Prosperity. Karnataka Journal of Agricultural Sciences, 13(2): 401-405.

Gangadharan, G. D. and Gopinath, G. 2000. Effect of organic and inorganic fertilizers on yield of spikes, corms, cormels and returns of gladiolus cv. White Prosperity. Karnataka Journal of Agricultural Sciences, 13(4): 937-941.

Gangadharan, G. D. and Gopinath, G. 2000. Effect of organic and inorganic fertilizers on growth, flowering and quality of gladiolus cv. White prosperity. Karnataka Journal of Agricultural Sciences, 11 (3): 401- 405.

Gaur, A.C. and Singh, G. 1995. Organic and biological plant nutrient sources: potential. methods for reducing the bulk and improving the availability of nutrients. In Integrated Plant Nutrition Systems. FAO Fertilizer and Plant Nutrition Bulletin, Vol. 12. pp. 85-112.
Gayathiri, M. and Anburani, A. 2011. Influence of integrated nutrient management on growth parameters of glory lily (Gloriosa superba L.). The Asian Journal of Horticulture. 6 (2): 358360.

Gayithri, H.N., Jaya Prasad, K.V. and Narayana Swamy, P. 2004. Response of biofertilizers and their combined application with different levels of inorganic fertilizers in Statice (Limonium sinuatum). Journal of Ornamental Hort., 7(1): $70-74$.

Godse, S. 2005. Effect of organic manures and biofertilizers with reduced doses of inorganic fertilizers on growth, flowering and yield of gladiolus. M.Sc. (Agri.) Thesis (Unpub.) Dr. PDKV, Akola.

Godse, S.B., Golliwar, V.J., Chopde, N., Bramhankar, K.S., Kore, M.S. 2006. Effect of organic manures and biofertilizers with reduced doses of inorganic fertilizers on growth, yield and quality of gladiolus. J. Soils and Crops, 16(2): 445-449.

Gruhn, P., Goletti, F. and Yudelman, M. 2000. Integrated nutrient management, soil fertility and sustainable agriculture: Current issues and future challenges. IFRPI 2020 Vision Brief.

Gupta, N. S., Sadavarte, K. L., Mahorkar, V. K., Jadhav, B. J. and Dorak, S. V. 1999. Effect of graded levels of nitrogen and bioinoculants on growth and yield of marigold. J. Soils and Crops, 9 (1): 80-83.

Gurav, S. B., Singh, B. R., Kakaije, D. S. Patil, M. T. and Ranpise, S. A. (2008). Integrated nutrient management in gerbera. In Book of abstracts. National Symposium on recent advances in Floriculture. 4-6 March Navsari. pp 45.

Hadwani, M.K., Varu, D.K., Panjiar, N., Babariya, V.J. 2013. Effect of integrated nutrient management on growth, yield and quality of ratoon tuberose (Polianthus tuborosa L.) cv. Double. The Asian Journals of Horticulture, 8(2): 448-451.

Haripriya, K. and Sriramachandrasekharan, M.V. 2002. Effect of organic amendments on the growth and yield of marigold in lignite mine soil. Advances in Plant Sciences, 15 (1): 177-179.

International Association of Horticultural Producers (AIPH) (2010) International Statistics Flowers and Plants, 2010

Jat, L.K., Singh, Y.V., Meena, Y., Meena, S.K., Meena, S.K., Parihar, M., Jatav, H.S., Meena, R.K., and Meena, V.S. 2015. Does integrated nutrient management (INM), enhance agricultural productivity?. Journal of Pure and Applied Microbiology 9(2): 1211-1221

Jawaharlal, M. and Padmadevi, K. 2003. Effect of biofertilizers on growth and flowering of anthurium (Anthurium andreanum Linn). Cv. 
Temptation. National Symposium Recent Advances in Indian Floriculture, Vellanikara, India, Kerala Agricultural University, p. 32-34.

Jayamma, N., Jagdish, K. S. and Patil, V. S. 2008. Growth and flower yield of jasmine (Jasminum auriculatum) as influenced by biofertilizers and graded doses of chemical fertilizes. Journal of Ornamental Horticulture, 11 (4): 275-280.

Jhon, A.Q. Mir, M.M., Neelofar and Khan, F.U. 2007. Response of organic manure and inorganic fertilizer on growth and bulb production in tulip (Tulipa gesneriana Linn.) Journal of Ornamental Horticulture, 10(3): 157-160

Kale, K., Banu, R. D., Sreenivas, M.N. and Bagyaraj, D.J. 1987 Influence of worm cast (Vee. Comp. E. UAS 83) on the growth and mycorrhizal colonization of two ornamental plants. South Indian Horticulture, 35 (6): 433-437.

Kashyap, R., Chaudhary, S.V.S., Dilta, B.S., Sharma, B.P., and Gupta, Y.C. 2013. Integrated nutrient management in tuberose (Polianthes tuberosa L.). International Journal of Farm Sciences, 4(1):55-59

Khanam, R., Kundu, D and Patra, S.K. 2017. Integrated nutrient management on growth, quality, yield and soil fertility of gladiolus in lower Gangetic Plain of India. Int.J.Curr.Microbiol.App.Sci., 6(4): 453-459

Khanna, P.R., Bohra, M., Punetha, P. and Nautiyal, B.P. (2016) Studies on the effect of organic manures and psb on vegetative and floral parameters of China aster (Callistephus chinensis (1.) ness.) cv. kamini under mid hills region of Himalaya. The Bioscan 11(4): $2707-$ 2710

Kirar, K.P.S., Lekhi, R., Sharma, S. and Sharma, R. (2009) Effect of integrated nutrient management practices on growth and flower yield of China aster (Callistephus clinensis (L.) ness] cv. Princess. Agriculture: Towards a New Paradigm of Sustainability, 234-237

Kulkarni, B.S., (1994) Effect of vermicompost on growth and flower yield of China aster (Callistephus chinensis). M. Sc. (Agri.) Thesis, University of Agricultural Sciences, Dharwad

Kumar, D., Singh, B.P. and Singh, D. 2009. Effect of integrated nutrient management on growth, flowering behaviour and yield of African marigold (Tagetes erecta L.) cv. African Giant Double Orange. J. Hort. Sci. 4 (2): 134-137

Kumar, M. 2014 Effect of different sources of nutrients on growth and flowering in tuberose (Polianthes tuberosa 1.) cv. "Vaibhav". Progressive Research, 9 (Special): 872-875.

Kumar, M. 2014. Effect of different sources of nutrients on growth and flowering in gladiolus
(Gladiolus hybridus Hort.) cv. Peater Pears. Annals of Horticulture 7(2): 154-158

Kumar, M. 2015. Flower and bulb production in tuberose (Polianthes tuberosa L.) cv. "Vaibhav" as influenced by different nutrients sources. HortFlora Res. Spect., 4(1): 56-59.

Kumar, M. 2015. Impact of different sources of nutrients on growth and flowering in chrysanthemum (Chrysanthemum morifolium Ramat.) cv Yellow Gold. Journal of Plant Development Sciences, 7(1): 49-53

Kumar, P., Raghava, S.P.S. and Mishra, R. L. (2003). Effect of biofertilizers on growth and yield of China aster. Journal of Ornamental Horticulture, (New series). 6 (2): 85-88.

Kumar, R., Singh, M., and Bera, B. 2015. Influence of organic, inorganic and combined based fertilizers on physiology of Darjeeling tea (Camellia sinensis L.). International Journal of Basic and Applied Biology, 2(4): 265-271.

Kumar, S., Singh, J.P., Mohan, B. and Rajbeer, N. 2013. Influence of integrated nutrient management on growth, flowering and yield parameters of marigold (Tagetes erecta L.) cv. Pusa Basanti Gainda. Asian Journal of Horticulture, 8(1): 111-121

Kumari, S. and Prasad, V.M. 2017. Effect of bio and chemical fertilizers on plant growth and yield of petunia (Petunia hybrid) var. Picotee. International Journal of Chemical Studies, 5(4): 1251-1254

Kumari, V. R., Kumar, D.P. Mahadevamma, M. and Arunkumar, B. 2013. Effect of integrated nutrient management on growth and floral parameters in gladiolus (Gladiolus hybridus L.) cv. American Beauty. Asian Journal of Horticulture, 8(1) 274-279

Kumawat, M., Khandelwal, S.K., Choudhary, M.R., Kumawat, P.K., Sharma, G. and Panwar. P. 2017. Effect of integrated nutrient management on growth, flowering and yield of African Marigold (Tagetes erecta L.). Int.J.Curr.Microbiol.App.Sci., 6 (8): 60-65

Kusuma, G. (2001) Effect of organic and inorganic fertilizers on growth, yield and quality of golden rod (Solidago Canadensis L.) M.Sc. (Agri.) Thesis. University of Agricultural Sciences, Bangalore.

Laishram, N, Dhiman, S. R., Gupta, Y.C. and Bhardwaj, S.K. 2010. Effect of integrated nutrient management on growth and flowering of China aster. In Book of abstracts. National Symposium on Lifestyle Floriculture: Challenges and Opportunities, March 19-21

Mahadik, M.K., Dalal, S.R. and Patil, D.A. 2017. Effect of integrated system of plant nutrition 
management on growth, yield and flower quality of chrysanthemum cv. PDKV Ragini. International Journal of Chemical Studies, 5 (5):881-886

Masaye, S. S. and Rangwala, A. D. 2009. Effect of different levels of NPK on flower quality of China aster (Callistephus chinensis (L.) Nees) var. Poornima. Annals of Agri. Bio. Rese., 14(2):153- 158 .

Mashaldi, A. 2000. Effect of organic and inorganic fertilizers on growth yield and post-harvest life of marigold (Tagetes erecta L.) cv. Double Orange. M.Sc (Ag) Thesis Univ. Agric. Sci., Bangalore

Mogal, S. A., Khiratkar, S. D., Chopde, N. K., Dalvi, A. M., Kuchanwar, O. D. and Khobragade, Y. R. 2006. Effect of organic manures and biofertilizers with reduced dose of nitrogen on growth, yield and quality of China aster. $J$. of Soil and Crops. 16 (1):180 -185

Moghadam, A.R.L., Ardebili, Z.O. and Fateme, S. 2012. Vermicompost induced changes in growth and development of Lilium Asiatic hybrid var. Navona. African Journal of Agricultural Research, 7(17): 2609-2621

Mohd, W., Jawaharlal, M., Arulmozhiayn, R. and Indhumathi, K. 2006. Effect of integrated nutrient management practices on flower quality and vase life of Anthurium andreanum cv. Maringue. Journal of Ornamental Horticulture. 9 (2): 142-144.

Mousavi, S.M. and Ardebili, Z.O. 2014. Growth and blossoming of lilium under various organic fertilizers. Iranian Journal of Plant Physiology, 5(1): 1235-1242.

Munikrishnappa, P.M., and Chandrasekhar, S.Y. 2014. Integrated nutrient management studies in China aster (Callistephus chinensis L. Nees): A Review, Trends in Bioscience, 7(12): 1217-1221

Munikrishnappa, P.M., Katimani, K.N. and Ravikumar, M. 2004. Effect of vermicompost on growth and yield of tuberose (Polianthes tuberosa L.) under semiarid tropics of north Karnataka. National symposium on Recent Trends and Future Strategies in Ornamental Horticulture, University of agricultural Sciences, Dharwad, pp: 61

Nagalakshmi, S., Sankari, A., Anand, M. and Arulmozhiyan, R. 2010. Organic stimulants on the growth and yield of Anthurium (Anthurium andreaum) cv. Verdun Red. Asian Journal of Horticulture. 5 (2): 450-452.

Naik, H.B., Shubha, B.M., Patil, B.C., Patil, A. and Chandrasekhar, S.Y. 2008. Effect of integrated nutrient management for carotenoid yield in African marigold. In Book of abstracts.
National Symposium on recent advances in Floriculture, 4-6 March Navsari. pp 54

Naik, R., Jayanthi, R. and Gangadharswamy, S.D. 2009. Effect of chemical fertilizers, biofertilizers and $\mathrm{GA}_{3}$ on growth and flowering of anthurium (Anthurium andrearum Lind.) cv. Red Crinkle. Paper presented in the International Conference on Horticulture held during 9-12 November, 2009, organized by Dr P.N. Agricultural Science Foundation, Bangalore, pp. 189.

Nandre D.R., Jogdande, N.D., Dalal, S.R., Bansode, A.B. and. Chaudhale, B.S. 2005. Effect of azotobacter on growth and yield of china aster under reduced nitrogen doses. Crop Res., 29 (2): 272-274.

Narasimharaju, S. and Haripriya, K. 2001. Integrated nutrient management in crossandra (Crossandra influndibuliformis L.) cv., Dindigul local. South Indian Horticulture, 49: 1818-184.

Narayanagowda, J. V. 2003. Effect of vermicompost and biofertilizers on growth and yield of gerbera (Gerbera jamesonii L.) cv. Local. National Symposium on Recent Advances in Indian Floriculture, Vellanikara, India, Kerala Agricultural University, p.19.

National Research Council, 1991. Integrated nutrient management for crop production. Toward sustainability: A plan for collaborative research on agriculture and natural resource management. Washington, DC: The National Academies Press. doi: 10.17226/1822

NCOF, 2014. National Centre of Organic Farming, Department of Agriculture \& Cooperation (DAC), Indian Fertilizer Scenario 2014, Department of Fertilizers, Ministry of Chemicals and Fertilizers, Government of India.

NCOF, 2015. National Centre of Organic Farming, Department of Agriculture \& Cooperation (DAC), Indian Fertilizer Scenario 2015, Department of Fertilizers, Ministry of Chemicals and Fertilizers, Government of India.

Nethra, N. N. 1996. Effect of organic and inorganic fertilizers on growth, yield and postharvest life of china aster (Callistephus chinensis (L.) Nees). M. Sc. (Hort.) Thesis, Univ. Agric. Sci., Bangalore

Padaganur, V. G., Mokashi, A. N. and Patil, V. S. 2005. Flowering, flower quality and yield of tuberose (Polianthes tuberosa L.) as influenced by vermicompost farmyard manure and fertilizers. Karnataka journal of Agriculture Science, 18 (3):729 -734

Padmadevi, K., Jawaharlal, M. and Vijayakumar, M. 2004. Effect of biofertilizers on floral characters and vase life of Anthurium (Anthurium 
andreanum Lind.) cv. Temptation. South Indian Horticulture, 52 (1-6): 228-231

Pandey, G., Kumar, S. and Kumar, A. 2010. Effect of integrated nutrient management on growth and flowering of chrysanthemum (Dendranthema grandiflora Tzvelev.). Journal of Ornamental Horticulture, 13(2): 112-116

Pandey, S.K., Kumari, S., Singh, D., Singh, V.K., Prasad, V.M. 2017. Effect of biofertilizers and organic manures on plant growth, flowering and tuber production of Dahlia (Dahlia variabilis L.) Cv. S.P. Kamala. Int. J. Pure App. Biosci., 5(2): 549- 555

Parya, C., Pal, B.K., and Biswas, J. 2010. Influence of integrated nutrient management on flower production efficiency, behaviour and quality of golden rod. Environment and Ecology, 28 (4): 2203-2205.

Patil, V.S., Chitra, R.S. and Jagdesh, K.S. 2007. Response of China aster to organic manure, biofertilizers and their combined applications with inorganic fertilizers. Asian Journal of Horticulture, 4 (1): 76- 77.

Pimpini, F and Zanin G. 2002. Gladiolus, the effect of soil type and fertilizer. Colture Protette, 31(9): 107-144.

Pindi, P.K. and Satyanarayana, S.D.V. 2012. Liquid microbial consortium- A potential tool for sustainable soil health. Journal of Biofertilizers \& Biopesticides, 3(4): 124. doi: 10.4172/21556202.1000124

Prakash, A., Sharma, S.K., Sindhu, S.S. and Prakash, A. 2002. Effect of phosphorous and FYM on NPK content of marigold in chloride dominated soil. Haryana Journal of Horticultural Sciences, 31 (1 \& 2): 47-49.

Pushkar, N.C., Rathore, S.V.S. and Upadhayay, D. K. 2008. Response of chemical and biofertilizer on growth and yield of African marigold (Tagetes erecta L.) cv. Pusa Narangi Gainda. Asian Journal of Horticulture. 3 (1): 130-132.

Rajadurai, K.R., Manivannan, K., JawahralaL, M. and Beaulah, B., 2000. Effect of Azospirillum and VAM on growth character of African marigold (Tagetes erecta L.). South Indian Hort. 48 (1-6): 83-87.

Ratti, N., Kumar, S., Verma, H.N. and Gautams, S.P. 2001. Improvement in bioavailability of tricalcium phosphate to Cymbopogon martini var. Motia by rhizobacteria, AMF and Azospirillum inoculation. Microbiology Research, 156: 145-149.

Ravichandran, M., 1991. Chemical and biological regulation on growth and flowering in crossandra. M. Sc. (Hort.) Thesis, Tamil Nadu Agricultural Sciences, Coimbatore.
Ravindra, S. P., Hanumanthappa, M., Hegde, J. N., Maheshwar, K. J. and Nagesha, L. 2013. Effect of integrated nutrient management on growth, yield and vase life of China aster (Callistephus chinensis (L.) Nees.) for coastal Karnataka. Environment and Ecology. 31(2): 1104- 1106.

Sabnavis, M., Urvisha, H. J. and Mishra, M. 2017. Indian fertilizer industry: Insights and prospects. CARE (Credit Research \& Analysis Limited July, 2017 pp. 15

Sangwan, P., Garg, V. K. and Kaushik, C. P. 2010. Growth and yield response of marigold to potting media containing vermicompost produced from different wastes. Earth and Environmental Science, 30 (2): 123 -130.

Sathyanarayana, E., Patil, S., Chawla S.L and Patel, D.K. 2017. Influence of integrated nutrient management on Gladiolus (Gladiolus Grandiflorus L.) cv. American Beauty. Int.J.Curr.Microbiol.App.Sci. 6(8): 379-386

Sharma, A., Saha, T.N., Arora, A., Shah, R. and Nain, L. 2017. Efficient microorganism compost benefits plant growth and improves soil health in calendula and marigold. Horticultural Plant Journal, 3 (2): 67-72

Sharma, B.P., Gautam, A., Gupta, Y.C., Dhiman, S.R. and Bhalla, R. 2010. Effect of foliar spray of biostimulants on growth and flowering of carnation cv. Sunrise. Journal of Ornamental Horticulture, 13 (2): 101-106.

Sharma, G., Sahu, N.P., and Shukla, N. 2017. Effect of bio-organic and inorganic nutrient sources on growth and flower production of African marigold. Horticulturae, 3: 11 ; doi:10.3390/horticulturae3010011

Sharma, U., Chaudhary, SVS, and Thakur, R. (2008) Response of gladiolus to integrated plant nutrient management. Haryana J. Hort. Sci., 37 (3\&4), 285-286

Shirsat, P.R., Kuchanwar, O.D., Ingale, S. N. 2015. Effect of integrated nutrient management on yield and nutrient content in tuberose. J. of Soils and Crops. 25 (2):.402-405

Shubha, B.M. 2006. Integrated nutrient management for growth, flowering and xanthophyll yield of marigold (Tagetes erecta L.). M.Sc. (Agri.) Thesis, University of Agricultural Sciences, Dharwad

Sims, T. T. Murphy, D. W. and Handweker, T. S. 1992. Com- posting of poultry wastes: Implication for dead poultry disposal and manure management," Journal of Sustainable Agriculture 2, (4): 67-82

Sindhu, S.S., Gopal, D.B., Rathore, A. and Dhiman, M. R. 2009. Effect of media amendments on physico-chemical properties and leaf nutrient 
concentration on gerbera (Gerbera jamesonii), Indian J. Agrl. Sciences, 79 (2):60.

Singh R., Kumar M., Raj, S. and Kumar, S. 2013. Effect of Integrated Nutrient Management (INM) on growth and flowering in gladiolus (Gladiolus grandiflorus L.) cv. "White Prosperity. Annals of Horticulture 6 (2): 242251

Singh R., Kumar M., Raj, S. and Kumar, S. 2014. Flowering and corm production in gladiolus (Gladiolus grandiflorus L.) cv. "White Prosperity" as influenced by Integrated Nutrient Management (INM). Annals of Horticulture. 7 (1): 36-42

Singh, A, Singh, A.K., and Yadava, L.P. 2014. Effect of integrated nutrient management on chemical properties of soil in the gladiolus crop field. Res. Environ. Life Sci., 7 (2): 87-90

Singh, B. R., Gurav, S. B. and Jadhav, S. B. (2010). Integrated nutrient management in carnation. In Book of abstracts. National Symposium on lifestyle floriculture. Challenges and Opportunities, March 19-21.

Singh, G. and Rathore, S.V.S. 2004. Flowering behaviour of tuberose (Polianthes tuberosa L.). as affected by application of organic and inorganic nutrient sources. National Symposium on Recent Trends and Future Strategies in Ornamental Horticulture, University of Agricultural Sciences, Dharwad, p. 58

Singh, M., Dwivedi, D.H., and Kumar, M. 2015. Effeciency of organic and biodynamic manures on growth and flowering in marigold (Tagetes patula L.) Progressive Agriculture, 15(1): 134137.

Singh, P, Prakash, S., Kumar, M., Kumar, S and Singh, M.K. 2015. Effect of Integrated Nutrient Management (INM) on growth, flowering and yield of marigold (Tagetes erecta L), Pusa Basanti. Annals of Horticulture, 8(1): 73-80.

Sivasankar, S and Manivannan, K. 2015. Effect of Integrated Nutrient Management (INM) on growth and yield of Glory lily (Gloriosa superba. L) International Journal of Current Advanced Research Research, 4(8): 275-277.

Smitha, A. Mogal, Khiratkar, S.D., Neha, K., Chopde, D., Ommala, A. M., Kuchanwar, D. and Khobragade, Y.R. 2006. Effect of organic manures and biofertilizers with reduced doses of nitrogen on growth, yield and quality of China aster. J. Soils and Crops, 16 (1): 180-185

Sonawane, S., Dabke, D. J., Dodake, S. B., Rathod, P. K. and Salvi, V. G. 2008. Effect of different levels of N, P and FYM on yield and quality of China aster (Callistephus chinensis L.) in lateritic soil of Konkan. J. Soils and Crops, 18(1):130-134

Sowmyamala, B. V., Nagaraju, H. T., Gopinath, K., Harinikuma, M. and Chandra, N. 2009. Effect of organic manures and inorganic fertilizers on growth, flower yield and shelf life of Gaillardia. In Book of abstracts. National Conference on Floriculture for Livehood and Profitability, 1619 March, IARI, New Delhi.

Srinivas, K. N. 1994. Effect of different compost on growth, yield and post-harvest life of China aster (Callistephus chinensis (L.) Nees). M. Sc. (Agri.) Thesis, Univ. Agric. Sci., Bangalore

Swamy, G.S. 2010. Integrated nutrient management in carnation (Dianthus caryophyllus L.) Cv. Dona under Polyhouse. Ph.D. (Hort.) Thesis, University of Agricultural Sciences, Bangalore.

Swathi, 2009. Studies on the effect of integrated nutrient management on growth, yield and vase life of China aster (Callistephus chinensis (L.) Nees.). M.Sc. (Hort.) Thesis Dr. Y.S.R Horticultural University, Tadepalligudem (AP).

Thane, S.R. Shembekar, R.Z. Bhongle, S.A. and Badge, S.A. 2007. Effect of integrated nutrient management on flower quality, yield and vase life of gerbera (Gerbera jamesonii H. Bolus) grown under shade net conditions. Plant Archives, 7 (2): 679-680.

Tripathi, S.K., Malik, S., Singh, I.P., Dhyani, B.P., Kumar, V, Dhaka, S.S. and Singh, J.P. 2012. Effect of integrated nutrient management on cut flower production of tuberose (Polianthes tuberosa L.) var. Suvasini. Annals of Horticulture, 5(1): 108- 15.

Verma, S.K., Angadi, S.G., Patil, V.S., Mokashi, A.N., Mathad, J.C. and Mummigatti, U.V. 2011. Growth, yield and quality of chrysanthemum (Chrysanthemum morifolium Ramat.) cv. Raja as influenced by integrated nutrient management. Karnataka J. Agric. Sci. 24 (5): 681-683

Wange, S.S., Patil, P.L. and Patil, J.J. 1995. Effect of biofertilizers alone and with nitrogen levels on tuberose cv. Single petated. J. of Soils and Crops, 5 (2): 97-99

Wani, M.A., Wani, S.A., Malik, S. Ahmad, R., Ahmed L., R, Gani, G., Khan, F.U and Neelofar. 2017. Integrated Nutrient Management (INM) approaches in flower crops. Int.J.Curr.Microbiol.App.Sci. 6(3): 254-265.

Witt, C. and Dobermann, A. 2004. Toward a decision support system for site-specific nutrient management. In: Dobermann, A., Witt, C. and Dawe, D. (Eds.), Increasing the productivity of intensive rice systems through site-specific nutrient management. Science Publishers, Inc., 
and International Rice Research Institute (IRRI), Enfield, NH (USA) and Los Baños (Philippines), 359-395.

Yadav, P.K., Singh, S., Dhidiwal, A.S. and Yadav, M.K. 2000. Effect of $\mathrm{N}$ and FYM application on floral characters and yield of African marigold (Tagetes erecta L.). Haryana Journal of Horticultural Sciences, 29 (1 \& 2): 69-71.

Yathindra, H. A., Manohar, R.K., Rajesh, A. M., and Harshavardhan, M. 2016. Effect of integrated nutrient management on growth parameters of bird of paradise (Strelitzia reginae (1.)). The Bioscan, 11(1): 565-568,

Zhang, F. S., Cui, Z. L., Fan, M. S., Zhang, W. F., Chen, X. P., and Jiang, Q. F. 2011. Integrated soil-crop system management: Reducing environmental risk while increasing crop productivity and improving nutrient use efficiency in China. J. Environ. Qual., 40: 1-7

Zhang, F. S., Shen, J. B., Li, L., and Liu, X. (2004). An overview of rhizosphere processes related with plant nutrition in major cropping systems in China. Plant Soil, 260: 89-99.

Zhang, F., Cui, Z., Chen, X., Ju, X., Shen, J., Chen, Q., Liu, X., Zhang, W., Mi, G., Fan, M. and Jiang, R. 2012. Integrated nutrient management for food security and environmental quality in China. Adv. Agron., 116: 1-40.

Zhang, F., Shen, J., Zhang, J., Zuo, Y., Li, L., and Chen, X. 2010. Rhizosphere processes and management for improving nutrient use efficiency and crop productivity: Implications for China. Adv. Agron., 107: 1-32.

\section{How to cite this article:}

Mukesh Kumar and Veena Chaudhary. 2018. Effect of Integrated Sources of Nutrients on Growth, Flowering, Yield and Soil Quality of Floricultural Crops: A Review. Int.J.Curr.Microbiol.App.Sci. 7(03): 2373-2404. doi: https://doi.org/10.20546/ijcmas.2018.703.278 